\title{
Alternatywne trendy konsumenckie w miejskich gospodarstwach domowych w Polsce w okresie kryzysu
}

\author{
Tomasz Zalega*
}

\begin{abstract}
Artykut jest poświęcony nowym trendom $w$ zachowaniach polskich gospodarstw domowych w okresie wspótczesnego kryzysu. Po omówieniu metodologii badania oraz cech próby badawczej $i$ jej charakterystyki, scharakteryzowano najważniejsze nowe trendy $w$ zakresie konsumpcji, dostrzeżone wśród respondentów, które nabieraty na sile w okresie kryzysu, takie jak: świadoma konsumpcja, sprytne zakupy, konsumpcja kolaboratywna, freeganizm, social media, wirtualna konsumpcja oraz domocentryzacja. Podsumowanie rozważań $i$ ważniejsze wnioski kończa niniejszy artykut.
\end{abstract}

Słowa kluczowe: nowe trendy, styl życia, konsumpcja, gospodarstwa domowe, zachowania konsumpcyjne, kryzys.

Nadesłany: 10.06.2013 | Zaakceptowany do druku: 25.10.2013

\section{Alternative consumption trends in Polish urban households in the period of crisis}

The article analyses new trends in the behaviour of Polish households during the present crisis. The description of the research methodology and the sample used is followed by a discussion of major consumption trends observed among the respondents, such as cocooning, conscious consumption, smart shopping, collaborative consumption, freeganism and use of social media, virtualization consumption, which become more pronounced in periods of crisis. The article concludes with a summation of the discussion and major conclusions.

Keywords: new trends, lifestyle, consumption, households, consumption behaviour, crisis.

Submitted: 10.06.2013 | Accepted: 25.10.2013

JEL: A12, C18, C46, D03, D12, D18

\footnotetext{
Prof. UW, dr hab. Tomasz Zalega - Wydział Zarządzania Uniwersytetu Warszawskiego.

Adres do korespondencji: Wydział Zarządzania Uniwersytet Warszawski, ul. Szturmowa 1/3, 02-678 Warszawa; e-mail: tomasz.zalega@wp.pl.
} 


\section{Wprowadzenie}

Kryzysy gospodarcze sa od dawna jednym z kluczowych zjawisk pojawiających się w ramach powtarzających się cyklicznie tendencji rozwojowych. W literaturze przedmiotu zagadnienie kryzysu może być rozpatrywane na wielu płaszczyznach: ekonomicznej, socjologicznej, psychologicznej czy filozoficznej. Z tego też względu trudno jest o zobiektywizowanie poglądów, analiz i prognoz w tym zakresie. Współczesny kryzys ma niewątpliwie charakter systemowy. Zdaniem wielu ekonomistów jest to kryzys neoliberalnego modelu kapitalizmu. W swojej początkowej fazie obecny kryzys nie wywołał odczuwalnych skutków w Polsce, jednakże w miarę pogłębiania się tendencji recesyjnych $\mathrm{w}$ gospodarce swiatowej, w swojej drugiej fazie, zaczął również negatywnie wpływać i na gospodarkę polską. Początkowo turbulencje na światowych rynkach finansowych ograniczały się w Polsce wyłącznie do rynków kapitałowych, w późniejszym zaś okresie znalazły swoje odzwierciedlenie także na rynkach pracy oraz dóbr konsumpcyjnych i usług (Zalega, 2012a, s. 23). Zmiany te nie pozostały bez wpływu na sytuację finansową polskich przedsiębiorstw i gospodarstw domowych. Pogarszająca się permanentnie sytuacja na rynku pracy wpłynęła bezpośrednio na sytuację materialną wielu polskich gospodarstw domowych, co z kolei znalazło swoje odbicie w zmianie poziomu i struktury konsumpcji oraz modyfikacji ich zachowań konsumpcyjnych na rynku (czyli nowych trendów). Analizując źródła kryzysu gospodarczego, należy brać pod uwagę oddziaływanie determinant o charakterze społecznym, polityczno-gospodarczym, technologicznym, strukturalnym i międzynarodowym. Ponadto wśród kluczowych przyczyn kryzysu, należy wskazać także na uboczne konsekwencje nadmiernej koncentracji na kreowaniu potrzeb, mających wyłącznie pozorne znaczenie dla konsumentów. Sprzyja to rozwojowi konsumpcjonizmu sakralizującego dostatek i spożywanie, dokonującemu się w warunkach silnej ekspansji marketingowej przedsiębiorstw ${ }^{1}$ oraz podmiotów rynku finansowego, oferujących szerokie możliwości nabywania produktów i usług na kredyt. Pobudza to konsumentów do nadmiernego zadłużania się $\mathrm{w}$ instytucjach bankowych i parabankowych, nieracjonalnego korzy- stania z kart kredytowych, tworząc zagrożenia związane z brakiem zabezpieczenia ich spłaty (Zalega, 2012b, s. 23). Należy w tym miejscu nadmienić, że posiadanie zwłaszcza kart kredytowych przez konsumentów, prowadzi w coraz większym zakresie nie tylko do wzrostu wydatków i nadmiernego zadłużania się, lecz także do uzależnień nazywanych „oniomanią2", będącą najbardziej widocznym przejawem cywilizacyjnej tendencji, która leży u podstaw społeczeństwa konsumpcyjnego. Natomiast w okresie kryzysu można zaobserwować wśród wielu członków gospodarstw domowych w Polsce tendencję do pewnej racjonalizacji zachowań nabywczych na rynku. Ponadto w odniesieniu do wielu konsumentów, kryzys zwiększa motywację do racjonalizowania struktur konsumpcji, ale również wyzwala ich dążenie do prostoty i nabywania produktów naturalnych, przyjaznych środowisku i zdrowych. Analiza kierunków zmian w strukturze konsumpcji i zachowaniach nabywczych miejskich gospodarstw domowych w Polsce rzuca nowe światło na kształtowanie się alternatywnych trendów konsumenckich obserwowanych w otoczeniu rynkowym.

Celem artykułu jest uchwycenie nowych trendów w zachowaniach miejskich gospodarstw domowych w Polsce, które nabierają na sile w okresie kryzysu gospodarczego. Po zaprezentowaniu metodologii badań oraz krótkiego opisu próby badawczej, w dalszej części artykułu w sposób syntetyczny przeanalizowano konsekwencje kryzysu gospodarczego odczuwane przez miejskie gospodarstwa domowe. Kolejnymi zagadnieniami poruszanymi w tekście są analiza alternatywnych trendów w zachowaniach nabywczych gospodarstw domowych w dziedzinie podejmowania decyzji konsumpcyjnych (świadoma konsumpcja, konsumpcja współpracująca, freeganizm, smart shopping, social media, wirtualna konsumpcja i domocentryzm) oraz strategie marketingowe podejmowane przez duże sieci handlowe i małe sklepy osiedlowe (głównie w kontekście smart shoppingu) w okresie kryzysu. Podsumowanie rozważań i ważniejsze wnioski kończą niniejszy tekst.

\section{Metodologia badania}

Zależności między kryzysem a kształtowaniem sie nowych trendów w zachowaniach polskich gospodarstw domowych 
stanowią istotny problem natury mikroi makroekonomicznej. Fragmentaryczne badania w tym zakresie prowadzone były przez różnego rodzaju instytucje i ośrodki naukowe. Wymienić wśród nich należy m.in. Instytut Badań Rynku, Konsumpcji i Koniunktur w Warszawie oraz Katedrę Badań Konsumpcji Uniwersytetu Ekonomicznego w Katowicach.

Należy wyraźnie podkreślić, że kryzys gospodarczy wywarł istotny wpływ nie tylko na poziom i strukturę konsumpcji, lecz także na zachowania konsumpcyjne polskich gospodarstw domowych. Niewątpliwie obserwowane w Polsce od 2008 roku spowolnienie tempa wzrostu gospodarczego rzutuje na pogorszenie się sytuacji na rynku pracy. To z kolei wpływa na sytuację dochodową konsumentów i efekcie prowadzi do obniżenia poziomu konsumpcji w niektórych gospodarstwach domowych oraz do jej pogorszenia. Oczywiście, w przypadku gospodarstw domowych, które pod wpływem kryzysu gospodarczego obniżają konsumpcję poniżej poziomu pozwalającego na zaspokojenie podstawowych potrzeb, poprawa koniunktury gospodarczej jest swoistym wyzwoleniem, ponieważ stwarza szanse powrotu do poziomu życia realizowanego przed pojawieniem się kryzysu. Nieco inaczej wygląda sytuacja wśród konsumentów, których kryzys gospodarczy skłonił do racjonalizacji wydatków i ograniczenia nadmiernej konsumpcji. Zdaniem K. MazurekŁopacińskiej (2010, s. 278), C. Shirky (2010, s. 114) i T. Zalegi (2012b, s. 222), takie reakcje gospodarstw domowych w obliczu krytyki konsumpcjonizmu mogą niewątpliwie sprzyjać weryfikacji zachowań także po zakończeniu kryzysu, który tym samym staje się ważnym determinantem pobudzającym do zmiany realizowanego modelu konsumpcji.

Podstawowym celem zaprojektowanych i przeprowadzonych badań empirycznych było uchwycenie struktury konsumpcji oraz specyfiki zachowań nabywczych miejskich gospodarstw domowych w Polsce w okresie kryzysu gospodarczego, ze szczególnym uwzględnieniem tzw. alternatywnych (nowych) trendów konsumenckich nabierających na sile w okresie kryzysu gospodarczego.

W badaniach szeroko pojmowanej konsumpcji wykorzystuje się wiedzę i dotychczasowe osiągnięcia teoretyczne i empiryczne, które są bardzo przydatne przy formułowaniu celów i hipotez badawczych, a także ułatwiają wyznaczanie zakresu przedmiotowego i przestrzennego potrzeb informacyjnych badań oraz zdefiniowanie podmiotów badania (Sojkin, Małecka, Olejniczak i Bakalarska, 2009; Zalega, 2012b). Z tego też względu sformułowanie szczegółowego zakresu przedmiotowego i przestrzennego badań zostało poprzedzone studiami literaturowymi w zakresie kryzysu gospodarczego, specyfiki zachowań konsumentów i nowych trendów konsumenckich w okresie spowolnienia tempa wzrostu gospodarczego oraz możliwości pomiaru i identyfikacji konsumpcji gospodarstw domowych.

Dla celów badawczych sformułowano 14 hipotez o charakterze ogólnym, które zostały zweryfikowane w następstwie przeprowadzonych badań. Biorąc pod uwagę temat niniejszego artykułu, sformułowano sześć hipotez badawczych:

1. Kryzys gospodarczy wpłynął na racjonalizację działań konsumentów oraz lepsze wykorzystanie posiadanych przez nich informacji na temat produktów dostępnych na rynku.

2. Najpopularniejszą strategią przystosowawczą do zmian wywołanych kryzysem wśród miejskich gospodarstw domowych jest racjonalizacja procesu decyzyjnego.

3. W okresie kryzysu następuje wzmocnienie postaw świadomości konsumenckiej oraz nasilenie tzw. konsumpcji kolaboratywnej.

4. Trendami nabierającymi na sile wśród miejskich gospodarstw domowych w Polsce w okresie kryzysu gospodarczego są: freeganizm, smart shopping, social media, wirtualna konsumpcja oraz domocentryzm.

5. Alternatywnym trendom konsumenckim ulegają przeważnie ludzie młodzi, legitymujący się wykształceniem średnim lub wyższym i zamieszkujący głównie duże miasta Polski.

6. Do zmiany zachowań konsumentów w postaci smart shoppingu, małe sklepy osiedlowe starają się wykorzystywać marketing relacyjny $\mathrm{i}$ marketing baz danych, a także podejmują starania bardziej ergonomicznej aranżacji przestrzeni sklepowej, natomiast sklepy wielkopowierzchniowe starają się reagować na dostrzeżone zmiany w zachowaniach nabywczych klientów poprzez wprowadzanie marek własnych w zakresie artykułów żywnościowych i nieżywnościo- 
wych, dbając przy tym o jakość i coraz większą różnorodność asortymentu.

W celu zebrania pełnych i aktualnych informacji na temat alternatywnych trendów w zachowaniach nabywczych polskich gospodarstw domowych w okresie kryzysu gospodarczego żyjacych w miastach, w badaniu bezpośrednim zastosowano metode wywiadu kwestionariuszowego. Metoda ta okazała się pomocna zarówno w opisie występujących zjawisk, jak i sprawdzeniu występowania określonych relacji między nimi a świadomością badanych Proces badania nowych trendów w gospodarstwach domowych w Polsce w okresie kryzysu podzielono na dwa zasadnicze obszary. I tak, w pierwszym obszarze skoncentrowano się głównie na rozpoznaniu nowych trendów, w drugim zaś - przede wszystkim na ocenie zachowań konsumenckich gospodarstw domowych w okresie kryzysu gospodarczego.

Przed przystąpieniem do badań zasadniczych przeprowadzono badania próbne na zbiorowości 20 gospodarstw domowych mieszkających w Warszawie. Ten pilotażowy wywiad kwestionariuszowy miał na celu sprawdzenie doboru i komunikatywności pytań zamieszczonych w kwestionariuszu ankietowym oraz prawidłowości układu ankiety. W efekcie tych badań dokonano poprawek w układzie kwestionariusza z niektórych pytań zrezygnowano i wprowadzono w ich miejsce nowe, inne natomiast zmodyfikowano. Należy również wspomnieć i o tym, że przy konstrukcji kwestionariusza wywiadu wykorzystano wypróbowane techniki stosowane powszechnie w badaniach rynkowych i marketingowych. Kwestionariusz wywiadu składał się z 35 pytań zasadniczych, głównie zamkniętych, w tym 7 o charakterze metryczkowym. Poszczególne grupy pytań zawarte w kwestionariuszu były ściśle skorelowane $\mathrm{z}$ kolejnymi etapami procesu decyzyjnego gospodarstw domowych w okresie kryzysu gospodarczego.

Struktura próby została tak dobrana, aby była identyczna ze struktura badanej zbiorowości w wybranych ośrodkach miejskich. $\mathrm{W}$ ten sposób wyeliminowano tzw. błąd pokrycia, który powstaje wówczas, gdy Z winy przeprowadzajacego ankiete niektóre grupy badanej populacji nie moga dostosować sie do próby ze wzgledu na źle dobrane przez ankietera miejsce przeprowadzenia badania. Mając to na uwadze autor przeprowadził badania w dużych dzielnicach mieszkaniowych oddalonych od ścisłego centrum miasta, zgodnie z mapka z wyznaczonym dla siebie obszarem badań.

Materiał empiryczny zawarty w pracy pochodzi z badań bezpośrednich przeprowadzonych $\mathrm{w}$ formie kwestionariusza ankietowego na próbie 1135 gospodarstw domowych w okresie od czerwca do sierpnia 2012 r. w ośmiu miastach Polski o zróżnicowanej liczbie ludności oraz wielkości. Zgodnie z przyjętymi założeniami badawczymi, w próbie znalazły się osoby powyżej 18. roku życia, które posiadały samodzielność finansową i podejmowały suwerenne decyzje nabywcze na rynku. W doborze próby zastosowano procedure doboru celowo-kwotowego. Przyjętymi w badaniu cechami (kwotami) były: płeć i wiek. Badania zostały przeprowadzone w ramach badań statutowych i w całości sfinansowane przez Wydział Zarządzania Uniwersytetu Warszawskiego.

Uzupełnieniem cech i właściwości charakteryzujących badaną próbę były tzw. badania eksplanacyjne, które zostały potraktowane przez autora badania jako dodatkowe uzupełnienie informacji uzyskanych w wyniku wywiadu kwestionariuszowego. W tym celu w pierwszej połowie września 2012 r. przeprowadzono spersonalizowane wywiady pogłębione z 23 osobami wybranymi w sposób celowy, biorąc pod uwage kluczowe cechy demograficzno-społeczne, takie jak: płeć, wiek, wykształcenie i miejsce zamieszkania. Wspomniane wywiady autor badań przeprowadził z osobami zamieszkałymi w Warszawie, Toruniu i Kostrzynie. Każdy z wywiadów trwał ok. 60 minut. Nastepnie przeprowadzone wywiady pogłębione transkrybowano i poddano analizie, zgodnie $\mathrm{z}$ metodyką prowadzenia badań jakościowych.

Zebrany w trakcie badań bezpośrednich materiał uporządkowano, tzn. poddano grupowaniu i zliczeniu oraz wstępnej ocenie pod względem kompletności informacji. Przeprowadzona weryfikacja i ocena zebranego materiału badawczego pozwoliła na wyeliminowanie błędów wypełnienia, niedokładności zapisów, błędów logicznych i systematycznych. Z wyjściowej liczby kwestionariuszy wywiadów wynoszącej 1214, zakwalifikowano 1135 kwestionariuszy, co stanowi $93,5 \%$ całości próby. W dalszym postępowaniu zostały one poddane procesowi kodowania, natomiast utworzony na ich bazie zbiór danych przetworzono pakie- 
tem statystycznym. Zastosowanie pakietu analizy statystycznej programu SPSS 14.0 PL umożliwiło dokonanie analizy informacji uzyskanych w wyniku przeprowadzenia badań metodą wywiadu standaryzowanego. Następnie po zgrupowaniu, zliczeniu i wstępnym opisie zebranych danych, dokonano ich analizy jakościowej i ilościowej. W tym celu wykorzystano współczynniki korelacji, głównie Pearsona, rang Spearmana, współczynnik zbieżności V-Cramera oraz współczynnik korelacji tau-b Kendalla. Należy w tym miejscu zaznaczyć, że kluczową metodą analizy statystycznej były tablice krzyżowe.

Otrzymane w wyniku wspomnianych analiz informacje umożliwiły dokonanie oceny zachowań nabywczych konsumentów oraz alternatywnych trendów konsumenckich w miejskich gospodarstwach domowych w Polsce w okresie kryzysu gospodarczego. Należy jednak zaznaczyć, że uzyskany materiał badawczy i zaprezentowane w artykule wyniki przeprowadzonego badania, mimo stosunkowo dużej próby, nie są na tyle dokładne, aby upoważniały do ich uogólnienia na populację generalną.

\section{Dobór próby badawczej i jej charakterystyka}

W badaniu uczestniczyło 52,9\% kobiet i $47,1 \%$ mężczyzn. Rozkład badanych według płci i wieku zgodny był z rozkładem populacji generalnej, dlatego też w próbie wystąpiła niewielka przewaga kobiet nad mężczyznami, najliczniejszą zaś grupę wiekową stanowiły osoby $\mathrm{z}$ przedziału 26-44 lata. Ważną zmienną przy badaniu konsumpcji jest miejsce zamieszkania. $\mathrm{W}$ próbie respondentów, zgodnie $\mathrm{z}$ przyjętymi założeniami badawczymi, znalazły się osoby zamieszkujące miasta o różnej liczbie mieszkańców i wielkości samego miasta, a mianowicie: Warszawę (powyżej 1 mln mieszkańców), Wrocław (powyżej 500 tys. mieszkańców), Gdańsk (powyżej 200 tys. mieszkańców), Toruń (powyżej 100 tys. mieszkańców), Suwałki (powyżej 50 tys. mieszkańców), Łowicz (powyżej 20 tys. mieszkańców), Brzesko w województwie małopolskim (powyżej 10 tys. mieszkańców) i Kostrzyn w woj. wielkopolskim (do 10 tys. mieszkańców) ${ }^{3}$. Każde miasto reprezentowało 139-150 osób, stanowiąc ok. $12-13 \%$ badanej próby (tab. 1$)$.
Tabela 1. Struktura respondentów i ich rodzin

\begin{tabular}{|c|c|c|}
\hline Cechy respondentów & \begin{tabular}{|c|} 
Liczba \\
respon- \\
dentów \\
$(\mathrm{N}=1135)$
\end{tabular} & $\begin{array}{l}\text { Udzial } \\
\text { procen- } \\
\text { towy }\end{array}$ \\
\hline $\begin{array}{l}\text { Płeć: } \\
\text { kobieta } \\
\text { mężczyzna }\end{array}$ & $\begin{array}{l}601 \\
534\end{array}$ & $\begin{array}{l}52,9 \\
47,1\end{array}$ \\
\hline $\begin{array}{l}\text { Wiek: } \\
\text { 18-25 lat } \\
\text { 26-44 lata } \\
\text { 45-64 lata } \\
65 \text { lat i więcej }\end{array}$ & $\begin{array}{l}121 \\
426 \\
364 \\
224\end{array}$ & $\begin{array}{l}10,7 \\
37,5 \\
32,1 \\
19,7\end{array}$ \\
\hline $\begin{array}{l}\text { Wykształcenie: } \\
\text { podstawowe } \\
\text { zasadnicze zawodowe } \\
\text { średnie ogólnokształ- } \\
\text { cące } \\
\text { wyższe }\end{array}$ & $\begin{array}{l}154 \\
242 \\
455 \\
284\end{array}$ & $\begin{array}{l}13,6 \\
21,3 \\
40,1 \\
25,0\end{array}$ \\
\hline $\begin{array}{l}\text { Liczba osób w gospodar- } \\
\text { stwie domowym: } \\
1 \text { osoba } \\
2 \text { osoby } \\
3 \text { osoby } \\
4 \text { osoby i więcej }\end{array}$ & $\begin{array}{l}159 \\
452 \\
320 \\
204\end{array}$ & $\begin{array}{l}14,0 \\
39,8 \\
28,2 \\
18,0\end{array}$ \\
\hline $\begin{array}{l}\text { Aktywność zawodowa: } \\
\text { pracujący } \\
\text { niepracujący }\end{array}$ & $\begin{array}{l}918 \\
217\end{array}$ & $\begin{array}{l}80,9 \\
15,1\end{array}$ \\
\hline $\begin{array}{l}\text { Dochód na } 1 \text { osobę } \\
\text { w gospodarstwie domo- } \\
\text { wym: } \\
\text { do } 1000,00 \mathrm{zl} \\
1001,00-2000,00 \mathrm{zl} \\
2001,00-3000,00 \mathrm{zl} \\
3001,00-4000,00 \mathrm{zl} \\
4001,00-5000,00 \mathrm{zl} \\
\text { powyżej } 5000,00 \mathrm{zl}\end{array}$ & $\begin{array}{r}192 \\
449 \\
339 \\
91 \\
39 \\
25\end{array}$ & $\begin{array}{r}16,9 \\
39,6 \\
29,9 \\
8,0 \\
3,4 \\
2,2\end{array}$ \\
\hline $\begin{array}{l}\text { Miejsce zamieszkania: } \\
\text { Warszawa } \\
\text { Wrocław } \\
\text { Gdańsk } \\
\text { Toruń } \\
\text { Suwałki } \\
\text { Łowicz } \\
\text { Brzesko (małopolskie) } \\
\text { Kostrzyn (wielkopolskie) }\end{array}$ & $\begin{array}{l}150 \\
144 \\
142 \\
140 \\
139 \\
140 \\
140 \\
140\end{array}$ & $\begin{array}{l}13,3 \\
12,7 \\
12,6 \\
12,3 \\
12,2 \\
12,3 \\
12,3 \\
12,3\end{array}$ \\
\hline
\end{tabular}

Źródło: badania własne. 
W badaniu zadano respondentom pytanie o poziom wykształcenia. W kwestionariuszu wywiadu przedstawiono cztery kategorie wykształcenia: podstawowe, zasadnicze zawodowe, średnie i wyższe. Najsilniej reprezentowane były osoby z wykształceniem średnim. Aż 2/5 ankietowanych legitymowało się tym poziomem wykształcenia. Co czwarty ankietowany uzyskał wykształcenie wyższe, natomiast co piąty respondent posiadał wykształcenie zasadnicze zawodowe. W badanej próbie najmniejszą grupę stanowiły osoby z wykształceniem podstawowym $(13,6 \%)$.

Warto także zwrócić uwagę, że ponad 4/5 respondentów było aktywnych zawodowo, nie pracowało natomiast szesnastu na stu badanych. Proporcja aktywnych i biernych zawodowo w badanej populacji jest zbliżona do tej, która odnosi się do krajowego rynku pracy.

Blisko $2 / 5$ badanych stanowiły osoby będące reprezentantami dwuosobowych gospodarstw domowych, natomiast co trzeci ankietowany reprezentował gospodarstwo trzyosobowe. $\mathrm{Z}$ kolei co piaty respondent pochodził $\mathrm{z}$ czteroosobowego gospodarstwa domowego, a jedynie jeden na siedmiu ankietowanych był przedstawicielem jednoosobowych gospodarstw domowych.

Wśród badanych $39,1 \%$ nie miało na utrzymaniu dzieci, natomiast $32,6 \%$ miało jedno dziecko, 23,5\% ankietowanych zaś - dwoje dzieci. Zaledwie co dwudziesty respondent reprezentował gospodarstwa domowe wielodzietne.

Prawie połowa respondentów określiła swoją sytuację ekonomiczną jako złą, a co trzeci ankietowany jako dobra. Prawie co dziesiąty respondent określił swój status ekonomiczny jako bardzo zły, natomiast zaledwie co dwudziesty ankietowany ocenił swoją obecną sytuację materialną jako bardzo dobra.

Największą grupę wśród respondentów stanowily osoby, których miesięczne dochody per capita mieściły się $\mathrm{w}$ przedziale 2001,00-3000,00 zł. Prawie dla co trzeciego ankietowanego miesięczny dochód na 1 osobę w gospodarstwie nie przekraczał 3000,00 zł. Dla co szóstego ankietowanego dochód nie przekraczał 1000,00 zł miesięcznie na 1 osobę w gospodarstwie domowym. Najmniejszą grupę wśród respondentów stanowiły gospodarstwa, w których dochód per capita wyniósł powyżej 5000,00 zł miesięcznie.

\section{Konsekwencje kryzysu gospodarczego odczuwane przez miejskie gospodarstwa domowe}

Kryzys gospodarczy bezpośrednio wpływa na pogorszenie się nastrojów konsumenckich, co z kolei ma swoje przełożenie na zachowania konsumpcyjne gospodarstw domowych. Jak dowodza w swoich pracach R.B. McKenzie (2010), E. Schargrodsky, R. Di Tella i S. Galiani (2010), M.R. Solomon, G. Bamossy, S. Askegaard i M.K. Hogg (2010) oraz T. Zalega (2012a), w okresie kryzysu następują zmiany modelu gospodarowania środkami pieniężnymi ze względu na ich kurczenie się, w efekcie czego zmniejsza się wielkość i wartość dokonywanych zakupów. Z kryzysem gospodarczym wiążą się przeważnie utrudnienia lub niemożność realizacji celów, duża niepewność zachowań konsumentów, problemy rzetelnej oceny przez nich sytuacji i potencjalnego ryzyka, również sytuacje konfliktowe i emocjonalne. Konsumenci w różnym stopniu podejmują działania pozwalające na zmniejszenie niepewności i złagodzenie skutków ekonomicznych kryzysu. Zdaniem R. Inklaar i J. Yang (2012, s. 478), zbyt późne dostrzeżenie oznak kryzysu lub udawanie, że ich nie ma, może utrudniać racjonalne wybory i pogłębiać niepewność utrzymania dotychczasowego poziomu życia. Według J. Grahama (2010, s. 204-205), postawy konsumenckie gospodarstw domowych w dobie kryzysu zmieniaja się $\mathrm{z}$ egocentrycznych na bardziej nastawione na rodzinę lub społeczność lokalną, ponieważ wzrasta udział decyzji podejmowanych wspólnie przez wszystkich członków gospodarstwa. Postrzeganie kryzysu przez konsumentów i jego ocena są ściśle skorelowane z wcześniejszymi doświadczeniami, poziomem życia i poczuciem bezpieczeństwa ekonomicznego jednostek. Każdy kryzys, bez względu na jego rozmiary i głębię, nie tylko rzutuje na gospodarkę, lecz także przyczynia się do zmian zachowań konsumenckich. Zmianie ulegaja zarówno pewne zwyczaje (np. płacenie gotówką czy wolumen kupowanych dóbr), jak i nastawienia konsumentów (np. do konsumpcji zrównoważonej, ekologicznej, przemyślanej). Podstawowym miernikiem reakcji konsumentów na kryzys gospodarczy jest spadek zaufania konsumpcyjnego. Z badań przeprowadzonych przez spółkę Nielsen (2009) w 50 krajach świata wynika, że ewidentną 
konsekwencją każdego kryzysu są dwa rodzaje zachowań konsumentów na rynku: kryzysowe i postkryzysowe. Pierwsze z nich są bezpośrednią reakcją konsumentów na kryzys i polegają głównie na redukcji bieżących wydatków konsumpcyjnych i ograniczeniu zaspokojenia potrzeb wyższego rzędu członków gospodarstwa domowego (Bohlen, Carlotti i Mihas, 2010, s. 18). Podobnego zdania są G. Desvaux, B. Regaout, B. Labaye, F. Yu i L. Mednonca (2009, s. 9-10), którzy dowodzą że w dobie kryzysu zachowania nabywcze wielu konsumentów są nakierowane na ograniczenie wielkości dokonywanych zakupów (kontrola wydatków, spędzanie czasu wolnego w domu) lub na ich eliminację oraz na obniżenie kosztów zakupu (poszukiwanie tańszych substytutów, zakupu online, korzystanie $\mathrm{z}$ porównywarek cen w Internecie). Również Ph. Kotler i J.A. Caslione są zdania, że w okresie kryzysu gospodarczego zachowania konsumenckie gospodarstw domowych przybieraja formy, takie jak: zwracanie sie ku tańszym produktom i markom (często markom własnym super- i hipermarketów), odwoływanie lub odkładanie zakupów dóbr luksusowych i drogich wakacji ograniczenie wyjazdów i kupowanie głównie w sklepach w okolicy domu lub pracy, czy też poświęcenie większej ilości czasu na przygotowanie i jedzenie posiłków w domu oraz korzystanie $\mathrm{z}$ domowych rozrywek, telewizji i Internetu (Kotler i Caslione, 2009, s. 151). Z kolei zachowania postkryzysowe ujawniają się jako kontynuowanie „nawyków kryzysowych” bądź polegają na zmianie stylu życia konsumentów w okresie po zakończeniu recesji (Hermann, 2009, s. 177). Jednakże, aby ten obraz zachowań konsumenckich na dobre się utrwalił i nie był postrzegany wyłącznie jako zachowania adaptacyjne konsumentów, zmiany te muszą zaistnieć w dłuższym odcinku czasowym.

Z badań przeprowadzonych przez spółkę Nielsena (2009) wynika, że w okresie kryzysu gospodarczego można zaobserwować ogólne tendencje w zakresie zachowań konsumenckich gospodarstw domowych, takie jak (www.trendwatching.com,http:// pl.nielsen.com/trends/documents/GlobalConsumerConfidenceConcernsandSpendingMay2009.pdfNielse):

1) zwiększenie udziatu zakupów w sklepach dyskontowych - konsumenci chętniej sięgają po marki własne sieci handlowych, których produkty są dużo tańsze od tych markowych;

2) staranniejsze przygotowanie się do zakupów - konsumenci, oprócz tradycyjnie sporządzanych list zakupów, używają list zakupowych wspomaganych nowoczesnymi technologiami (np. Kraft - aplikacja dla iPhona zawiera przepisy na niedrogie dania i umożliwia tworzenie w telefonie listy zakupów);

3) korzystanie z obniżek $i$ wyprzedaży - konsumenci starają się nie wydawać jednorazowo zbyt dużych kwot pieniężnych; w tym celu chętniej kupują doraźnie, rozkładając zakupy na różne dni tygodnia, poszukując oszczędności w większej liczbie placówek i doceniając mniejsze sklepy i bazarki osiedlowe;

4) szukanie $w$ Internecie informacji oraz miejsc tańszych zakupów - konsumenci, wykorzystując blogi i portale internetowe (np. Zaradni.pl), szukają oszczędności w domowych budżetach;

5) moda na gotowanie „od podstaw” - konsumenci nie tylko realizują tańszy wymiar konsumpcji, przy którym nie szacuja wartości własnego czasu poświęconego na przygotowanie potraw, lecz także wprowadzają nowe trendy odżywiania - kuchnie lokalne, jedzenie dietetyczne i ekologiczne.

Z przeprowadzonych badań wynika, że prawie $3 / 5$ ankietowanych twierdziła, że ich gospodarstwo domowe realnie odczuło skutki kryzysu gospodarczego. Prawie 2/3 respondentów stwierdziło, że w wyniku kryzysu pogorszyła sie sytuacja materialna w ich rodzinie. Około $20 \%$ ankietowanych miało problem z określeniem oceny wpływu kryzysu na własne gospodarstwo domowe. Niewątpliwie najważniejszym skutkiem kryzysu gospodarczego wydaje się być zwiększenie poczucia niepewności wśród respondentów. Ponad $2 / 5$ badanych było zdania, że obecnie ma większe niż przed kryzysem obawy dotyczące sytuacji materialnej swojej rodziny, prawie $1 / 3$ respondentów obawia sie utraty pracy przez współmałżonka, a $32 \%$ ankietowanych podkreślało, że nie jest w stanie niczego zaplanować. Należy w tym miejscu zwrócić uwagę na istotną statystycznie korelację, jaka zachodzi pomiędzy wysokością miesięcznych dochodów ankietowanych a postrzeganiem oceny wpływu kryzysu na ich rodziny oraz gospodarstwa domowe ich znajomych. Im wyższym rozporządzalnym dochodem dyspono- 
wali respondenci, tym częściej dostrzegali przejawy kryzysu w swoich rodzinach oraz gospodarstwach domowych krewnych i znajomych (współczynnik korelacji tau-b Kendalla $=0,624, p \leq 0,01)$.

Respondenci, którzy sygnalizowali odczuwanie negatywnych konsekwencji kryzysu gospodarczego w swoich gospodarstwach domowych czesto twierdzili, że kondycja finansowa ich rodzin pogorszyła się na tyle, że zmuszone zostały podjąć różne środki zaradcze odnośnie do stanu i struktury konsumpcji. Z przeprowadzonych badań wynika, że ponad $2 / 3$ z tych, których sytuacja finansowa pogorszyła się w porównaniu z okresem sprzed kryzysu, zaczęła racjonalizować zakupy. Owa racjonalizacja zakupów podjęta przez respondentów, przejawiała się w poszukiwaniu tańszych produktów kosztem ich droższych odpowiedników (44,2\% wskazań), rezygnacji z pewnych zakupów i usług (42,8\% wskazań) bądź korzystaniu z różnego rodzaju promocji organizowanych przez sieci dyskontowe oraz super- i hipermarkety (39,8\% wskazań). Jak potwierdzają przeprowadzone badania w zakresie zachowań gospodarstw domowych na rynku, w pierwszej kolejności ograniczeniu podlegają głównie produkty zaspokajające potrzeby mniej pilne, których konsumpcja może zostać odłożona w czasie $(52,1 \%$ wskazań). Najlepszym tego przykładem są potrzeby w zakresie kultury i wypoczynku, które nie należą do najpilniejszych, dlatego też w sytuacji ograniczonych możliwości finansowych gospodarstwa domowego, w pierwszej kolejności następuje ich redukcja $(60,1 \%$ wskazań). Zaprezentowane zachowania konsumpcyjne można tłumaczyć wzrostem niepewności wynikającej ze zwiększającego się bezrobocia koniunkturalnego (cyklicznego), będącego następstwem spadającego popytu na pracę ze strony pracodawców.

Określenie konsekwencji kryzysu gospodarczego uzależnione jest w dużej mierze od sytuacji materialnej badanych. Nasilenie przejawów kryzysu częściej odnosiło się do tych gospodarstw domowych, w których respondent dysponował miesięcznym dochodem per capita do 1000,00 zł (83,9\% wskazań). Wraz ze wzrostem zamożności ankietowanych odsetek ten malał (wspó1czynnik korelacji tau-b Kendalla $=0,614$, $(p \leq 0,01)$ (tab. 2).

W świetle przeprowadzonych analiz statystycznych okazało się, że konsekwencje kryzysu gospodarczego są częściej dostrzegane przez kobiety niż mężczyzn. Ocena skutków przejawu kryzysu była prawie 2-krotnie wyższa wśród kobiet niż wśród mężczyzn. Respondenci, realnie dostrzegający konsekwencje kryzysu w swoich rodzinach, najczęściej wymieniali spadek dochodów - co drugi badany wskazywał te odpowiedź. Co piąty ankietowany starał się utrzymać konsumpcję w swoich gospodarstwie na dotychczasowym poziomie, korzystając głównie z nagromadzonych wcześniej oszczędności. W odniesieniu do tej grupy ankietowanych można zatem dostrzec występowanie w praktyce działania efektu rygla (zapadki), zręcznie opisanego w literaturze ekonomicznej przez J.S. Duesenberry'ego (1952, s. 194). Co dziesiąty badany na skutek spowolnienia tempa wzrostu gospodarczego utracił pracę, co trzeci zaś zmuszony został do zrezygnowania $\mathrm{z}$ wzięcia kredytu bankowego z obawy

Tabela 2. Skutki kryzysu odczuwane przez ankietowane gospodarstwa domowe (w \%)

\begin{tabular}{|l|c|c|}
\hline \multicolumn{1}{|c|}{ Opinie respondentów o skutkach kryzysu gospodarczego } & $\begin{array}{c}\text { Liczba } \\
\text { respondentów } \\
\text { N=1135 }\end{array}$ & $\begin{array}{c}\text { Udzial } \\
\text { procentowy }\end{array}$ \\
\hline Spadek dochodów & 581 & 51,2 \\
\hline Utrzymanie konsumpcji na dotychczasowym poziomie & 236 & 20,8 \\
\hline Brak odczuwania skutków kryzysu & 59 & 5,2 \\
\hline Utrata pracy & 117 & 10,3 \\
\hline $\begin{array}{l}\text { Rezygnacja z wzięcia kredytu bankowego z obawy o niemożliwość } \\
\text { jego spłaty }\end{array}$ & 339 & 29,9 \\
\hline Wycofanie pieniędzy z banku & 346 & 30,5 \\
\hline
\end{tabular}

Źródło: badania własne.

Wydział Zarządzania UW ～DOI 10.7172/1733-9758.2013.16.4 
przed problemami z jego spłatą. Tyle samo respondentów wycofało swoje oszczędności z banku, obawiając się niewypłacalności sektora bankowego w okresie turbulencji finansowych. W związku z tym kryzys pobudzał ankietowanych do oszczędzania, które, według ich deklaracji, będzie kontynuowane (w różnym zakresie) także po wystąpieniu poprawy sytuacji gospodarczej.

Ankietowane gospodarstwa domowe o najniższych miesięcznych dochodach per capita nieprzekraczających 1000,00 zł, których sytuacja materialna w okresie kryzysu uległa ewidentnemu pogorszeniu, w największym stopniu zaczęły podejmować kroki zaradcze i asekuracyjne. Podejmowane przez konsumentów działania ograniczały się z jednej strony do zmniejszenia swoich wydatków, z drugiej zaś - polegały na odkładaniu w czasie większych zakupów dóbr, których niedobór nie rzutuje w istotny sposób na bieżący poziom satysfakcji z konsumpcji. Takie postępowanie respondentów znalazło swoje odbicie w określonych postawach wobec kryzysu gospodarczego. $Z$ przeprowadzonych badań ewidentnie wynika, że ankietowani, których miesięczny dochód na 1 osobę w gospodarstwie nie przekracza 1000,00 zl, najczęściej utożsamiali się z różnymi sytuacjami wynikającymi z wystąpienia kryzysu, m.in. ograniczali wydatki konsumpcyjne, poszukiwali tańszych substytutów, deklarowali racjonalniejsze zużywanie wody, gazu i energii elektrycznej, deklarowali bardziej oszczedne eksploatowanie samochodu, mniejsze wydatki na usługi finansowe, ograniczali bądź całkowicie rezygnowali z wypoczynku, szukali okazji i przecen itd. Ponadto co trzeci respondent z najniższej grupy dochodowej wykazywał zdolności adaptacyjne do nowych realiów spowodowanych kryzysem gospodarczym przez podejmowanie pracy w szarej strefie, pozwalającej uzyskać dodatkowe dochody i w ten sposób podreperować nadszarpnięte kryzysem budżety gospodarstw domowych. Można zatem powiedzieć, że kryzys gospodarczy wpłynął na pewna racjonalizację działań konsumentów. Więcej z nich zaczęło planować decyzje zwiazane z zakupem produktów, większy był też stopień wykorzystania informacji. Respondenci, którzy poszukiwali tańszych ofert, „łapiąc okazje" zmuszeni byli do zbierania informacji w celu ich porównania, aby przekonać się czy wyprzedaż była faktycznie atrakcyjną okazją.

\section{Nowe trendy w zachowaniach konsumenckich gospodarstw domowych w okresie kryzysu - wprowadzenie}

Przez pojecie „trend” rozumie się istniejacy w danym momencie kierunek rozwoju w jakiejś dziedzinie bądź bardziej ogólnie - monotoniczny składnik zależności badanej cechy od czasu. Znawca tematu H. Vejlgaard (2008, s. 9) definiuje trend jako proces zmiany, który jest ujmowany z perspektywy psychologicznej, ekonomicznej lub socjologicznej, mogący mieć charakter krótko- lub długookresowy oraz zasieg regionalny lub globalny. $\mathrm{Z}$ tego punktu widzenia trend $\mathrm{w}$ zachowaniach konsumenckich jest najczęściej pojmowany w literaturze przedmiotu jako określony kierunek zmiany w stylu życia modelowego konsumenta, który działa w sposób obiektywny, czyli niezależnie od woli i świadomości. W szerszym ujęciu można powiedzieć, że trendy w sferze konsumpcji powstają na skutek oddziaływania otoczenia w wymiarze: społecznym, ekonomicznym, prawnym, politycznym, demograficznym i technologicznym na zachowania nabywcze konsumentów i w efekcie rzutuja na zmiany wzorców konsumpcji. Zdaniem F. Shawa (2009), pojawiajace sie trendy konsumenckie wpływają na sposób funkcjonowania przedsiębiorstw, tworząc tym samym nowe reguły funkcjonowania współczesnych organizacji. Natomiast podstawowymi cechami trendów są ich zmienność, wzajemne nakładanie się (współwystępowanie) oraz jednoczesne pojawianie się kontrtrendów (dywergencja). Z kolei przez „nowe” lub „,alternatywne" trendy konsumenckie można rozumieć obiektywne i długoterminowe kierunki ogólnych wyborów, zachowań i preferencji konsumentów będące konsekwencja przemian społeczno-politycznych, prawnych, kulturowych, demograficznych i technologicznych, permanentnie dokonujących się w otoczeniu rynkowym. Należy również pamiętać i o tym, że zarówno badanie, jak i analiza trendów sprowadzają się w dużym stopniu do wnioskowania dedukcyjnego, bazującego na szerokim spektrum trudnych do uogólnienia obserwacji.

Według P. Flatters i M. Willmott (2009, s. 109-112), w okresie kryzysu gospodarczego znacznej modyfikacji ulegają trendy obserwowane w otoczeniu rynkowym. Jak dowodzą autorzy, w warunkach pogorszenia 
sytuacji gospodarczej niektóre trendy słabną (serwicyzacja i konsumeryzm ekologiczny), wyhamowują (konsumpcjonizm i konsumpcja ostentacyjna), dominują (samozaopatrzenie i wzrost krytycyzmu) bądź przybierają na sile ('swiadoma konsumpcja, konsumpcja współpracująca, freeganizm, social media, wirtualizacja konsumpcji, smart shopping oraz domocentryzm).

\section{5. Świadoma konsumpcja i konsumpcja współpracująca}

W okresie kryzysu gospodarczego następuje wzmocnienie postaw świadomej konsumpcji, zwanej także, szczególnie w krajach anglosaskich, ,etyczną konsumpcją", „odpowiedzialną konsumpcją" lub konsumpcją zrównoważonego rozwoju. Świadoma konsumpcja jest pochodną ekokonsumpcji, konsumeryzmu i dekonsumpcji. Jest ona rozumiana jako podejmowanie wyborów konsumenckich w oparciu o wiedzę na temat ich społecznych, ekologicznych i politycznych konsekwencji ${ }^{4}$. W praktyce świadoma konsumpcja oznacza zdobywanie informacji na temat produktów i usług - praktyk stojących za nimi firm, procesu produkcji, możliwości utylizacji i na ich podstawie dokonywanie możliwie społecznie i ekologicznie odpowiedzialnych wyborów (www.fed.home.pl/teg/images/m1_swiadoma_konsumpcja_fin.pdf). Jednak̇̄e ze świadōmą konsumpcją mamy do czynienia zarówno wtedy, kiedy kupujemy produkty i usługi przyjazne dla ludzi i środowiska, jak i gdy zostawiamy portfel w kieszeni i szukamy lepszych rozwiązań ${ }^{5}$. Świadczy to o tym, że my jako konsumenci powoli zmieniamy się w społeczeństwo konsumpcyjne, gdzie „mieć” coraz częściej staje się „być”. Należy wszakże pamiętać, że świadoma konsumpcja eksploruje takie rozwiązania, jak redukcja użycia, współdzielenie i używanie ponowne produktów. Ponadto w etycznej (świadomej) konsumpcji ważne jest także branie pod uwagę całego życia produktu, nie tylko tego jak powstał, lecz także co się z nim stanie, kiedy przestanie być potrzebny. Produktami związanymi ze wspomnianym trendem są wyroby rękodzielnicze i o niskim stopniu przetworzenia, cała grupa produktów określanych mianem slow food ${ }^{6}$, czyli: slow life, slow travel, slow parenting i slow city. W okresie kryzysu wymienialnie ubrań i up-cycling (przetwarzanie odpadów w coś o jeszcze większej wartości) ponownie stały się modne (Zalega, 2012b, s. 225). Ponadto świadoma konsumpcja wiąże się z oszczędnym spożyciem wody i energii, ograniczeniem wykorzystania chemii, recyklingiem produktów i energii oraz rozwojem budownictwa pasywnego. Takie racjonalne patrzenie na kwestie konsumpcji w okresie kryzysu gospodarczego i szukanie alternatyw dla zakupu nowych produktów potwierdziło zaledwie $19 \%$ ankietowanych. Najwięcej gospodarstw domowych podejmujących decyzje konsumpcyjne w oparciu o świadomą konsumpcję pochodziło z Warszawy (31,3\%) i Wrocławia $(22,9 \%)$, a najmniej z Brzeska $(3,7 \%)$ i Kostrzyna $(2,7 \%)$. Zaledwie $31,6 \%$ respondentów było zdania, że dokonała wyboru konsumenckiego w oparciu o społeczną reputację firmy, a niespełna $21 \%$ deklarowała, że zrezygnowała z jakiegoś zakupu ze względu na aspekty społeczne lub ekologiczne. Taką odpowiedź wskazywali głównie mieszkańcy dużych miast: Warszawy $(51,6 \%)$, Wrocławia $(47,6 \%)$ i Gdańska $(41,1 \%)$. Należy również zaznaczyć, że ponad $2 / 5$ respondentów regularnie kupuje w osiedlowych sklepach i od lokalnych dostawców. Odnosi się to głównie do mieszkańców mniejszych miast, takich jak Suwałki (52,6\%), Łowicz $(51,3 \%)$ i Brzesko $(47,6 \%)$. Z przeprowadzonych badań wynika ponadto, że odsetek deklarujących kontakt ze świadomą konsumpcją był większy wśród kobiet niż mężczyzn. Prawie $43 \%$ respondentów twierdziło, że przynajmniej raz w życiu zdarzyło im się uczestniczyć w wydarzeniu związanym $z$ promocją idei świadomej konsumpcji bądź sprawiedliwego handlu (Fair Trade). Były to przeważnie kobiety, z grupy wiekowej 26-44 lat, legitymujące się wykształceniem średnim i wyższym, dysponujące miesięcznym dochodem na 1 osobę powyżej 3000,00 zł, zamieszkujące Warszawę, Wrocław i Gdańsk. Należy w tym miejscu zaznaczyć, że ruch świadomej konsumpcji rozwija się dynamicznie w Polsce, szczególnie w dużych miastach. Natomiast w małych miastach, do 50 tys. mieszkańców (Łowicz, Brzesko i Kostrzyn), trend ten ma charakter śladowy.

W okresie kryzysu gospodarczego dynamicznie rozwijającym się podejściem do świadomej konsumpcji jest tzw. konsumpcja współpracująca, zwana również sharing'iem, mesh'em, „konsumpcją kolaboratywną” lub „ekonomią dzieloną”. Jest ona 
jednym z wielu nowych trendów występujących w zachowaniach współczesnych gospodarstw domowych i przybrała na sile w okresie kryzysu gospodarczego w wielu krajach na świecie. Sharing zdaniem R. Botsman i R. Rogers (2012, s. 15-16) oraz L. Gansky (2010, s. 56) jest modelem konsumpcji, który polega m.in. na pożyczaniu, wymianie, umowach barterowych lub płatnym dostępie do dóbr, stojącym w opozycji do własności ${ }^{7}$. Prawie co dziesiąty respondent informował, że w celu ograniczenia wydatków związanych z zakupem odzieży, książek i szeroko rozumianych akcesoriów dziecięcych dokonał bezgotówkowej wymiany niepotrzebnych ubrań, niechcianych prezentów oraz dziecięcych ubranek, obuwia lub zabawek. Takie postępowanie konsumentów jest określane w literaturze przedmiotu jako clothswap 8 lub toyswap. Tego typu zachowania asekuracyjne podejmowane przez gospodarstwa domowe w okresie kryzysu gospodarczego wskazywali najczęściej mieszkańcy Torunia $(18,3 \%)$ i Warszawy $(16,9 \%)$. Były to przeważnie kobiety legitymujące się wykształceniem zasadniczym zawodowym i średnim ogólnokształcącym, dysponujące miesięcznym dochodem rozporządzalnym per capita nieprzekraczającym 2000,00 zł. $\mathrm{Z}$ kolei co piętnasty badany twierdził, że w celu pozyskania dodatkowych środków pieniężnych w okresie kryzysu, wykorzystując serwis internetowy, odpłatnie udostępnił na krótki okres jeden $\mathrm{z}$ wolnych pokoi w swoim mieszkaniu/domu w wybranym przez siebie okresie. Takie postępowanie konsumentów jest określane mianem roomsharingu. Odpowiedź tę wskazywali głównie respondenci pochodzący z Gdańska $(11,2 \%)$ i Torunia $(7,9 \%)$. Były to przeważnie osoby z grupy wiekowej 26-44 lata, legitymujące się wykształceniem średnim ogólnokształcącym lub wyższym oraz osiągające miesięczne dochody na 1 osobę poniżej 3000,00 zł.

\section{Freeganizm - alternatywny styl życia i poszukiwanie oryginalności}

Dynamicznie rozwijającym się zachowaniem konsumentów w okresie kryzysu gospodarczego, dostrzeżonym także wśród ankietowanych, jest trend do oszczędzania i dokonywania racjonalnych zakupów oraz minimalizowania konsumpcji. Trend ten jest jednym ze źródeł rozwoju tzw. fre- eganizmu, czyli ruchu zorientowanego na racjonalizację gospodarowania zasobami i zmniejszenie marnotrawstwa produktów (zarówno żywnościowych i nieżywnościowych) w handlu i gospodarstwach domowych. Ten antykonsumpcyjny styl życia powstał w Stanach Zjednoczonych Ameryki w drugiej połowie lat 90. XX w. Słowo „freeganzim” pochodzi z połączenia dwóch angielskich słów: free - wolny, darmowy i veganism - weganizm, czyli styl życia, który polega na unikaniu produktów pochodzenia zwierzęcego. Jednakże sam termin może być mylący, freeganem może bowiem zostać nawet ortodoksyjny mięsożerca. Freeganami są często LOHAS (Lifestyles of Health and Sustainability), czyli konsumenci, którzy są zainteresowani zdrowiem, środowiskiem naturalnym, sprawiedliwościa społeczna, zrównoważonym stylem życia i rozwojem osobistym ${ }^{9}$. Ruch freeganizmu bardzo szybko rozprzestrzenił się w wielu krajach Europy Zachodniej, zwłaszcza w Niemczech, Hiszpanii i Portugalii, gdzie zyskał masowy charakter. W niektórych miastach Europy, takich jak: Barcelona, Berlin czy Madryt, powstały nawet specjalne przewodniki dla freegan, w których opisano nie tylko miejsca, gdzie można za darmo otrzymać jedzenie bądź wymienić rzeczy, lecz także godziny, w których najlepiej się tam pojawić. Przeważnie sa to kontenery znajdujace się przy hotelach, restauracjach, barach szybkiej obsługi, cukierniach i piekarniach. Natomiast w Polsce informacje o freeganizmie można znaleźć jedynie w Internecie. Mimo to jest w naszym kraju wielu ludzi, którzy poprzez swoje działania wpisują się w ten ruch społeczny.

Freegańska filozofia „etycznego jedzenia" głosi, że kapitalizm i masowa produkcja opierają się na wyzysku pracowników, zwierząt i środowiska naturalnego. Z tego też względu freeganizm jest postrzegany jako antykonsumpcyjny styl życia, sprowadzający się do ograniczenia udziału w ekonomii i obejmuje zarówno poszukiwanie żywności w śmietnikach, jak i proszenie o nadmiarowe i niepotrzebne produkty, zanim zostaną wyrzucone przez sprzedawców z targowisk osiedlowych, restauracji czy dużych sieci handlowych. Stąd skłonność konsumentów do korzystania z produktów używanych oraz produktów wycofanych z sieci. Chodzi tu przede wszystkim o darmowe nabywanie produktów nieeste- 
tycznych, uszkodzonych lub lekko przeterminowanych, zanim zostaną one wyrzucone przez handlowców. Freeganie nie ograniczają się wyłącznie do poszukiwania żywności, ale poszukują także wyrzuconych ubrań i butów, sprzętu elektronicznego, a nawet nadających się do zaakceptowania, opuszczonych przestrzeni miejskich (www. elejdis.pl/692,Freeganizm). Freeganizm to także naprawianie popsutych przedmiotów zamiast ich wyrzucania, DIY (do it yourself, czyli zrób to sam), dzielenie się tym co się ma, wymienianie się rzeczami z innymi ludźmi i zadawanie sobie zawsze pytania zanim się coś kupi „Czy rzeczywiście potrzebuję danego produktu?" (www.m.onet.pl/biznes,cbjb). Można zatem powiedzieć, że zwolennicy freeganizmu kontestują galopujący konsumpcjonizm, gonienie za komercyjnymi nowościami, ostro sprzeciwiają się szaleństwu konsumpcji i przy okazji dobrze się bawią. Freegan, w odróżnieniu od osób, których na ulicę wypędza bieda, stać na wysoki standard życia, natomiast w sposób świadomy rezygnują z nadmiernego konsumpcjonizmu, traktując freeganizm jako określony styl życia. Należy w tym miejscu zaznaczyć, że ich działalność ma także wymiar ekologiczny, ponieważ zgodnie $\mathrm{z}$ zasadą: reduce, resuse i recycle sprawiają, że wiele produktów dzięki nim zostaje ponownie wykorzystana i nie trafia na wysypiska śmieci (www.biznesodpowiedzialnie.blog.pl/tag/kontenerowcy).

Freeganizm jest niewatpliwie moda na oszczędny styl życia, natomiast osoby uważające się za freegan są na ogół dobrze wykształcone, mieszkają w dobrych dzielnicach dużych miast i wielu z nich do pracy jeździ dobrej klasy samochodem. Można wymienić pięć kluczowych zasad, którymi kierują się freeganie: odzyskiwanie odpadów (w tym żywności), minimalizację ilości produkowanych odpadów, ekologiczny transport (począwszy od jeżdżenia komunikacja publiczną, poprzez używanie ekologicznych paliw, aż po autostop), squatting oznaczający uspołecznienie niewykorzystanych mieszkań, samowystarczalność (wyszukiwanie jedzenia w śmietnikach i uprawa warzyw i owoców na własny użytek oraz tworzenie przedmiotów codziennego użytku) oraz ograniczenie pracy, w celu poświęcenia większej ilości czasu rodzinie i społeczności lokalnej.

W Polsce freeganizm dopiero raczkuje, jednakże w okresie kryzysu nabiera na sile i zdobywa wielu zwolenników. Polscy zwolennicy freeganizmu określani są mianem „kontenerowców” bądź ,śmieciowych nurków". Wielu polskich konsumentów jeszcze nie nasyciło się mnogością produktów znajdujących się w supermarketach i galeriach handlowych, co po części można tłumaczyć okresem komunizmu, który cechował się permanentnym niedoborem rynkowym. Jednakże perspektywy rozwoju freeganizmu w Polsce są duże, zwłaszcza w dużych miastach i wśród studentów oraz młodych ludzi, którym znudziło się życie w korporacyjnych szklanych gmachach i jedzenie lunchy w drogich restauracjach. W Polsce, ze względu na obowiązujące prawo, zarządzający super- i hipermarketami mają obowiązek przeterminowaną bądź uszkodzona żywność zniszczyć lub wyrzucić na śmietnik zamykany na lańcuchy i kłódki (w wielu krajach Europy Zachodniej niektóre sieci hipermarketów zabezpieczają odpady przed bakteriami z myślą o freeganach, w efekcie czego kontenerowcy otrzymuja żywność zaś sklepy wielkopowierzchniowe są łaskawiej traktowane przez alterglobalistów). Jednakże coraz więcej hoteli i właścicieli restauracji, zwłaszcza w dużych miastach w Polsce, wystawia na zapleczu swoich lokali niesprzedane w danym dniu potrawy. Ponadto wielu sprzedawców sklepów osiedlowych i lokalnych targowisk odkłada w określone dni tygodnia, do specjalnie oznaczonych kartonów, warzywa i owoce oraz nabiał. Tego typu praktyki stosowane przez restauratorów i sprzedawców na osiedlowych targowiskach potwierdziło ponad 4/5 ankietowanych przyznających się do uprawiania freeganizmu, zamieszkałych w Warszawie, Wrocławiu, Gdańsku i Toruniu.

Z przeprowadzonych badań wynika, że wśród badanych jedynie co dwudziesty piąty ankietowany przyznał się do nabywania produktów żywnościowych z przysłowiowego śmietnika. Byli to przeważnie respondenci młodzi do 25. roku życia oraz osoby z grupy wiekowej 26-44 lata, przeważnie mężczyźni, legitymujący się wykształceniem średnim ogólnokształcącym lub wyższym, posiadający miesięczne dochody per capita nieprzekraczające 4000,00 zł i mieszkający najczęściej w Warszawie $(5,4 \%)$, Wrocławiu $(3,9 \%)$, Gdańsku $(3,8 \%)$ i Toruniu $(2,7 \%)$. Ankietowani, których można uznać za freegan, najczęściej pozyskiwali nieodpłatnie warzywa i owoce, pieczywo oraz nabiał (głównie sery twarde, jogurty, twarożki 
i serki homogenizowane). Wspomniane produkty były pozyskiwane przeważnie na osiedlowych targowiskach oraz na zapleczu dyskontów (głównie Lidla i Biedronki), mniejszych sklepów osiedlowych i delikatesów.

Konstatujac zjawisko freeganizmu w Polsce, można stwierdzić, że ten trend konsumencki utożsamiany $\mathrm{z}$ nurkowaniem ludzi w śmieciach i zbieraniem żywności, którą wyrzucamy do kosza, jest, i wszystko na to wskazuje, że pozostanie, alternatywnym i niszowym stylem życia, ponieważ z jednej strony - polskie społeczeństwo jest konserwatywno-hierarchiczne, z drugiej zaś - dla większości Polaków bycie kontenerowcem nie mieści się w ich mentalności.

\section{Smart shopping - podstawa pragmatycznego i kalkulującego konsumenta}

Smart shopping jest trendem konsumenckim nabierającym na sile w okresie kryzysu gospodarczego. W dosłownym tłumaczeniu z języka angielskiego smart shopping oznacza „sprytne zakupy”. Są one rozumiane jako inwestowanie własnego czasu w poszukiwanie informacji o promocjach, porównywanie cen różnych produktów (m.in. dzięki korzystaniu z przeglądarek internetowych), łapanie okazji, „nieprzepłacanie” i niekierowanie się emocjami podsycanymi przez reklamy oraz oszczędzanie pieniędzy. Innymi słowy, idea smart shoppingu propaguje racjonalne planowanie budżetu domowego poprzez kupowanie rzeczy niezbędnych w niskiej cenie oraz tych, które rzeczywiście zamierzaliśmy kupić. Podwalin sprytnych zakupów można doszukiwać się w skutkach światowego kryzysu gospodarczego z 2008 r. Z tego też względu można śmiało powiedzieć, że ojcem sprytnych zakupów jest Internet, natomiast matką zła koniunktura gospodarcza. Przez wielu ekonomistów smart shopping jest traktowany jako typowy trend postrecesyjny $i$ to o znaczeniu globalnym. Jeszcze inni traktują go jako element alternatywnego stylu życia i poszukiwania oryginalności. Dla uprawiających smart shopping istotne znaczenie ma stosunek jakości produktu do jego ceny, a także skład, funkcjonalność i niezbędność jego posiadania. Stąd też ten trend jest najbardziej popularny wśród osób lepiej wykształconych, którzy w pełni świadomie podejmują decyzje o zakupie produktów lub usług. Osoby słabiej wykształcone mają z reguły większy problem z prawidłową analizą i oceną ofert, które przez producentów są celowo konstruowane w zawiły i mało czytelny sposób. W konsekwencji osoby te wybierają produkty tańsze, ale niższej jakości lub w ogóle rezygnują z zakupów. Należy jednak pamiętać, że kupując niedrogo produkty nietrwałe, konsumenci muszą wymieniać je częściej, więc oszczędności są pozorne. Wśród respondentów legitymujących się wykształceniem podstawowym lub zasadniczym zawodowym aż 71,6\% stwierdziła, że robiąc zakupy szuka promocji i przecen, zaś $51,5 \%$ była zdania, że robiąc zakupy zawsze szuka najniższych cen. Natomiast wśród ankietowanych $\mathrm{z}$ wykształceniem wyższym ponad połowa stwierdziła, że podejmując decyzję o zakupie dóbr i usług dokonuje analizy i oceny oferty, biorąc pod uwagę nie tylko cenę samego produktu lecz także jego jakość, skład i funkcjonalność. Potwierdza to dobitnie stwierdzenie, że smart shopping jest najbardziej popularny wśród zamożniejszych i lepiej wykształconych konsumentów.

Z przeprowadzonych badań wynika jednoznacznie, że najwięcej tzw. smart shopperów jest wśród kobiet, z grupy wiekowej 45-64 lata, legitymujących się wykształceniem wyższym i zamieszkujących głównie większe miasta, takie jak Warszawa, Wrocław i Gdańsk. Z badania wynika także, że respondenci posiadający miesięczny dochód per capita powyżej 4000,00 zł byli bardziej nastawieni na poszukiwanie oszczędności przy zakupach zarówno produktów żywnościowych, jak i nieżywnościowych, głównie odzieży i obuwia. Spośród ankietowanych o najwyższych miesięcznych dochodach na 1 osobę w rodzinie i wyższym poziomie wykształcenia aż $76,4 \%$ była zdania, że w przypadku ubrań i produktów żywnościowych w miarę latwo jest zdecydować o takich kwestiach, jak to czy jakość produktu jest odpowiednia do ceny, jaki maja one skład i czy są w ogóle funkcjonalne. Prawie $23 \%$ respondentów (głównie z Warszawy, Wrocławia i Gdańska) odwiedzała tzw. centra outletowe, które są esencją smart shoppingu, ponieważ udostępniają dobrej jakości asortyment po cenach niższych o $30-70 \%$ od tych samych produktów w innych sklepach. 


\section{Smart shopping a miejsce robienia zakupów i strategie marketingowe handlowców}

Trend, jakim jest smart shopping, łączy się z korzystaniem $\mathrm{z}$ ofert różnych typów handlu. Oferta sprzedaży dóbr jest bardzo zróżnicowana, a sklepy coraz silniej konkurują ze sobą. Dla współczesnych konsumentów istotne znaczenie ma możliwość kupienia wszystkich zaplanowanych produktów $\mathrm{w}$ jednym miejscu. W związku z tym ważne jest, aby sklep był dobrze zaopatrzony i nie miał braków na półkach. Konsumenci uważający się za tzw. smart shopperów chcą łatwo i w miarę szybko znaleźć wszystko czego potrzebują, dlatego też bardzo ważna jest organizacja sklepu i odpowiedni sposób ekspozycji produktów. Każdy konsument oczekuje, że sklep zaoferuje mu dobrą relację jakości do ceny. Coraz ważniejsza staje się także atmosfera robienia zakupów. To czynnik, który ma coraz większą siłę w różnicowaniu sklepów. Ponadto tzw. smart shopperzy nauczyli się już, że więcej zyskają, odwiedzając różnego rodzaju sklepy (dyskontowe, osiedlowe), super- i hipermarkety, ale również i targowiska osiedlowe.

W okresie kryzysu gospodarczego zakupy na targowiskach i małych sklepach osiedlowych ponownie wróciły do łask. Z przeprowadzonych badań wynika, że kryzys okazał się sprzymierzeńcem tak sklepów osiedlowych, jak i bazarów, które utrzymując minimalny asortyment, bronią się swoją bliskością wobec konsumenta i defensywnym sposobem inwestowania. Ponad $31 \%$ ankietowanych, uważających się za tzw. smart shopperów, stwierdziła, że kryzys gospodarczy ewidentnie przyczynił się do częstszego robienia przez nich zakupów na targowiskach i w małych sklepach osiedlowych. Najczęściej zakupy w małych sklepach osiedlowych robili mieszkańcy Warszawy (32,6\% wskazań) i Wrocławia (30,5\% wskazań), najrzadziej zaś respondenci mieszkający w Suwałkach (23,1\% wskazań) i Kostrzynie (22,6\% wskazań). Były to przeważnie kobiety z grupy wiekowej 45-64 lata oraz 65 i więcej lat, legitymujące się wykształceniem średnim zawodowym i wyższym, dysponujące miesięcznym dochodem na 1 osobę powyżej 1000,00 zł. Respondenci robiacy zakupy w małych sklepach i na osiedlowych bazarach najczęściej kupowali warzywa i owoce (89,2\% wskazań), wędliny $(59,3 \%$ wska- zań), mięso (54,6\% wskazań), drób (37,9\% wskazań) i nabiał (29,1\% wskazań). Natomiast wśród artykułów nieżywnościowych największą popularnością wśród kupujących cieszyła się odzież (57,7\% wskazań), obuwie (41,4\% wskazań) oraz kosmetyki (36,2\% wskazań).

Według ankietowanych dokonujących systematycznie zakupów w małych sklepach osiedlowych i na targowiskach, robienie zakupów w tych sklepach ma wiele pozytywnych cech. Należą do nich: świeżość kupowanej żywności (76,2\% wskazań), bliskość miejsca zamieszkania $(65,1 \%$ wskazań), możliwość zamówienia konkretnego towaru, którego nie ma na ogół w asortymencie (57,2\% wskazań), a także miła obsługa i zaufanie do sprzedawcy $(56,6 \%$ wskazań).

Aby zachęcić konsumentów do częstszego robienia zakupów, właściciele małych sklepów osiedlowych coraz częściej wykorzystują marketing relacyjny, który bazuje na budowaniu pewnej więzi sprzedawcy z konsumentami, w efekcie czego wzrasta ich przywiązanie do firmy. Coraz większe znaczenie $\mathrm{w}$ budowaniu więzi $\mathrm{z}$ konsumentami ma także marketing baz danych. Pozwala on na śledzenie nawyków zakupowych konsumentów oraz opracowywanie produktów i przesłań odpowiednio dopasowanych do potrzeb i pragnień ludzi na podstawie uzyskanych informacji, w wyniku czego wrasta też jakość obsługi klientów. W praktyce przejawia się to $\mathrm{w}$ tym, że sprzedawca, znając upodobania konsumentów, sprowadza najbardziej preferowane przez nich (pod względem ceny, jakości, opakowania, marki itd.) produkty. Ponadto właściciele sklepów osiedlowych, aby konkurować z dużymi sieciami handlowymi, starają się komfortowo zaaranżować przestrzeń sklepową (wygodne rozłożenie półek sklepowych, intuicyjny rozkład produktów), co pozwala konsumentom zaoszczędzić czas przeznaczony na robienie zakupów.

Sprzedaż detaliczna jest systemem, w którym istotna role odgrywa cena produktu. Dlatego też małe sklepy osiedlowe mają małe szanse, aby konkurować na tym polu z dużymi sieciami handlowymi. Należy również wspomnieć i o tym, że sklepy osiedlowe i te zlokalizowane na osiedlowych bazarach, mają droższą ofertę niż dynamicznie rozwijające się sklepy internetowe, które oferują klientom zakupy bez wychodzenia $\mathrm{z}$ domu. $\mathrm{Z}$ powyższych przyczyn, 
małe sklepy systematycznie znikają z rynku (zwłaszcza w centrach dużych miast) i coraz częściej wchodzą w skład większych organizacji i sieci franczyzowych.

Hipermarkety, podobnie jak sklepy dyskontowe, zapewniają szeroki, chociaż płytki wybór asortymentu oraz atrakcyjną dla konsumentów cenę towarów. Ponadto przyjęcie przez sklepy dyskontowe, takie jak: Biedronka i Lidl oraz hipermarkety: Tesco i Auchan nowej strategii: Kupuj tanio bez kompromisu dla jakości produktu jest dla małych sklepów osiedlowych ogromnym wyzwaniem i zagrożeniem, powinno jednak skłaniać ich właścicieli do większej dbałości o jakość i różnorodność towaru oraz budowania relacji partnerskich $\mathrm{z}$ klientem i zaskakiwaniem go nowymi pomysłami i dodatkowymi usługami. Ponieważ cena produktu jest dla wielu konsumentów ważnym determinantem decydującym o zakupie produktów, nie ma się co dziwić, że wielkopowierzchniowe sklepy handlowe oraz sklepy dyskontowe sa miejscem robienia zakupów najczęściej wybieranym przez konsumentów o przeciętnym lub niskim dochodzie wrażliwych na promocje i komplementarność oferty, a także zasobniejszych konsumentów szukających różnych okazji cenowych.

$\mathrm{Z}$ badania cen koszyka 20 produktów, przeprowadzonego w 2011 r. przez firmę Nielsen dla „Rzeczpospolitej”, wynika, że w małych sklepach osiedlowych zakupy są wciąż najdroższe. Za te same produkty konsument zapłaci w nich średnio o $27 \%$ więcej niż w sieci dyskontów: Biedronka, Lidl, Netto czy Aldi (www.rp.pl/artykul/590077 Kleska-malychsklepow-na-rynku-coraz-gorzej.html).

W strategię smart shoppingu wpisuje się kupowanie przez konsumentów produktów własnych marek. Tendencja ta nie dotyczy jednak wszystkich kategorii produktowych w równym stopniu. Wybór tańszego produktu musi odwoływać się do zaufania. Zauważalne są dwa poziomy zaufania do marek własnych, a mianowicie: oparte na zaufaniu do producenta (np. Biedronka) bądź na zaufaniu do sieci (np. Lidl). Należy pamiętać o tym, że każdy wybór może być postracjonalizowany $\mathrm{z}$ perspektywy konsumenta, co w efekcie ma przełożenie na duże prawdopodobieństwo ponownego zakupu. W okresie kryzysu gospodarczego wiele gospodarstw domowych dysponuje mniejszymi miesięcznymi rozporządzal- nymi dochodami. Sytuację tę wykorzystują z powodzeniem duże sieci handlowe, np. Tesco, Carrefour, Auchan, Lidl czy Biedronka, które wypuszczają na rynek własne produkty, często gorszej jakości. Jednakże podstawową ich zaletą jest stosunkowo niska cena względem produktów markowych, które są rozpoznawalne na rynku i dobrze znane konsumentom. Wprowadzenie marek własnych pozwala na zmniejszenie kosztów przeznaczanych na reklamę i promocję, ponieważ koszty te rozkładają się na budżety promocji samej sieci handlowej i producenta. Owa strategia własnych, tańszych produktów odnosi się nie tylko do żywności (np. herbata, mrożonki, twarogi i sery), lecz także coraz częściej do artykułów nieżywnościowych (np. proszków do prania, baterii elektrycznych, odzieży, obuwia, rowerów). Produkty te sa adresowane głównie do ludzi mniej zamożnych, którzy przy robieniu zakupów największą wage przywiązują do ceny produktów. Natomiast takie czynniki, jak: jakość, marka czy efektowne opakowanie mają dużo mniejszy wpływ na ostateczną decyzję zakupu (Zalega, 2008, s. 47). Od pewnego czasu pod marką własną sprzedawane są jednak również produkty z wyższej półki (np. wino, kosmetyki), a także produkty specjalistyczne (np. ubezpieczenia Tesco). Pozyskanie klientów kupujących takie produkty może być korzystne nie tylko dla samej sieci handlowej, lecz także dla konsumentów. Z przeprowadzonych badań wynika, że 43,6\% respondentów potwierdziło kupowanie produktów marek własnych oferowanych przez sieci handlowe (głównie Biedronkę, Lidl i Tesco). Wśród ankietowanych nabywających produkty marek własnych, co trzeci zakupuje takie produkty często, prawie co piąty badany nabywa je regularnie, niespełna $10 \%$ respondentów - sporadycznie, natomiast $2 / 5$ badanych nie kupuje i w ogóle nie jest zainteresowana ich nabywaniem. Takie zachowania konsumentów wpisują się w strategię smart shoppingu i są dla wielu ankietowanych powodem do dumy, ponieważ „kupując marki własne”, „świadomie dokonują wyboru produktów” i "są sprytni, bo nie przepłacają". Należy w tym miejscu zaznaczyć, że marki własne, początkowo traktowane czysto produktowo i kupowane ze względu na niską cenę, stają się coraz częściej nośnikiem jakości i wizerunku.

Na podstawie wyników badania można stwierdzić, że prawie $2 / 5$ respondentów 
regularnie dokonuje zakupów w sklepach dyskontowych (głównie w Biedronce, Lidlu i Aldi), co trzeci badany preferuje zaś robienie zakupów w hipermarketach (najczęściej w Tesco, Carrefour i Auchan). Najbardziej przywiązani do robienia zakupów w sklepach dyskontowych są ankietowani z grupy wiekowej 45-64 lata, posiadający wykształcenie podstawowe i zasadnicze zawodowe, o miesięcznym dochodzie rozporządzalnym na 1 osobę nieprzekraczającym 2000,00 zł zamieszkujący Toruń (48,7\%), Suwałki (45,3\%), Łowicz $(44,2 \%)$ i Kostrzyn $(43,6 \%)$. Z kolei dokonywanie zakupów w hipermarketach preferowali głównie młodzi ankietowani do 25 . roku życia oraz respondenci z grupy wiekowej 26-44 lata, legitymujący się wykształceniem średnim ogólnokształcącym i wyższym, dysponujący miesiecznym dochodem per capita powyżej 3000,00 zł oraz zamieszkujący większe miasta: Warszawę $(51,3 \%)$, Gdańsk $(46,2 \%)$ i Wrocław $(43,9 \%)$.

Konstatując, można powiedzieć, że trend, jakim są „sprytne zakupy”, niewątpliwie przyczynił się w Polsce w okresie kryzysu gospodarczego do zmian w strukturze sprzedaży poprzez dynamiczny rozwój centrów outletowych, wzrostu udziału sieci dyskontowych i marek własnych oraz e-handlu.

\section{Social media - cybernetyczny konsumpcjonizm}

W kształtowaniu reakcji konsumentów na kryzys gospodarczy warto zwrócić uwagę na rolę, jaką odgrywają internetowe kontakty z innymi konsumentami, które pozwalają na dzielenie się opiniami dotyczacymi produktów, marek i organizacji rynkowych. Trend ten określa się w literaturze przedmiotu mianem social media, czyli w dosłownym tłumaczeniu z języka angielskiego „mediami społecznościowymi”. Termin ten został po raz pierwszy zastosowany przez H. Rheingolda w $1993 \mathrm{r}$. Według A.M. Kaplana i M. Haenlein (2010, s. 61-62; 2012, s. 101-102), media społecznościowe stanowią grupę aplikacji, które opierają się na rozwiązaniach internetowych, bazuja na technologicznych i ideologicznych podstawach Web 2.0 oraz umożliwiają użytkownikom tworzenie i wymianę wygenerowanych przez nich treści. Najczęściej występują one pod postacią m.in.: blogów i mikroblogów (np. Blip, Twitter), społeczności kontaktowych (np. YouTube, Vimeo, Wikipedia), serwisów społecznościowych (np. Facebook, Nk.pl), wirtualnych światów gier (np. Word of Warcraft) i wirtualnych światów społecznościowych (np. Second Life). Popularność mediów społecznościowych we współczesnym zglobalizowanym świecie sprawia, że trend ten trzeba rozpatrywać jako niezwykle istotny czynnik wpływający na styl i tryb życia współczesnych gospodarstw domowych oraz na podejmowane przez nie decyzje konsumpcyjne. Nowoczesne technologie informacyjne, zwłaszcza komputery, Internet, multiroomy, smartfony, tablety i telefony komórkowe, stanowia jedno z ważniejszych źródeł uświadomienia potrzeb konsumentom dzięki temu, że pozwalają na uzyskanie informacji o różnych produktach, sprzyjają ujawnianiu sie nowych potrzeb (poprzez dostrzeżenie nowych produktów w Internecie), a także wpływają na zmianę oczekiwań w stosunku do produktu. Wszystko to sprawia, że dostep współczesnych gospodarstw domowych do informacji o produktach jest szeroki, samo zaś uzyskanie informacji jest moźliwe na odległość i w jednym miejscu.

Mobilny dostęp do Internetu sprawia, że coraz więcej osób może angażować się w działania w mediach społecznościowych bez względu na czas i lokalizację. Uczestnicy serwisów społecznościowych nawiązują lub odnawiają kontakty, prezentują własną twórczość, komentuja wydarzenia, wymieniają informacje i prowadzą życie towarzyskie. Dla wielu osób przeżywanie świata w życiu wirtualnym jest ciekawsze niż w realnym. Cześciowo dzieje sie tak, ponieważ społeczności wirtualne oferują dostęp do osób i form aktywności nieosiagalnych w inny sposób. Ponad $65 \%$ internautów deklaruje, że tworzy własne treści, które później publikuje m.in. w social media. Serwisy internetowe sieci społecznościowych i blogów są odwiedzane przez 4 na 5 aktywnych użytkowników Internetu, w tych serwisach spedza sie $25 \%$ czasu korzystania z sieci, a $40 \%$ ich użytkowników ogląda zawartość mediów społecznościowych z urządzenia przenośnego (NM Incite, A Nielsen/McKinsey Company, www.nmincite.com State of the Media: Social Media Report Q3). Według firmy badawczej comScore, korzystanie z mediów społecznościowych to obecnie najpopularniejsza forma aktywności osób z grupy wiekowej 
18-24 lata w Internecie. Na każde 5 minut surfowania prawie minutę pochłania kontaktowanie się ze znajomymi za pomocą Facebooka, ćwierkanie na Twisterze czy też „check-inowanie” na Foursquare. Z niemal 1,5 miliardowej rzeszy użytkowników sieci aż 1,2 mld (82\%) korzysta z serwisów społecznościowych czy mikrologów. Taki odsetek utrzymuje się już od 2007 r. Wówczas social media pochłaniały zaledwie $6 \%$ czasu specdzanego online. W $2011 \mathrm{r}$. liczba ta oscylowała wokół 20\% (http:// www.socialpress.pl/2011/12/ponad-miliardinternautow-korzysta-z-social-media?\#). Należy również pamiętać i o tym, że uczestnicy portali społecznościowych, jako najbardziej aktywni internauci, kształtują rzeczywistość, wpływając w ten sposób na wizerunek marek oraz podmiotów rynkowych. Według badań spółki Nielsena przeprowadzonych w czwartym kwartale 2012 r. dla pasażu Empik.com wynika, że mężczyźni częściej niż kobiety korzystają z zakupów internetowych. Zakupy w sieci robi $56 \%$ mężczyzn i zaledwie $44 \%$ kobiet. Jednakże to kobiety częściej niż mężczyźni wykorzystują Internet do szukania informacji o produktach przed dokonaniem zakupów (www.interaktywnie.com/biznes/ newsy/biznes/tak-wyglda-konsumpcja-internetu-wsrod.mezczyzn-i-kobiet-245942).

Z przeprowadzonych badań wynika, że ponad $91 \%$ respondentów korzystających $\mathrm{z}$ Internetu, czyli prawie $3 / 5$ badanej próby, przynajmniej raz $\mathrm{w}$ tygodniu sprawdza pocztę elektroniczną, ok. 2/3 badanych - przegląda strony www, 34,5\% ankietowanych - aktywnie korzysta z portali społecznościowych, natomiast co trzeci respondent rozmawia przez komunikator internetowy (np. Skype czy GG). Należy w tym miejscu nadmienić, że obecność na portalach społecznościowych jest dla wielu osób istotną formą komunikacji z innymi ludźmi. Zasięg serwisów społecznościowych w Polsce wynosi 90,6\%, co gwarantuje nam drugie miejsce w Europie po Turcji pod względem korzystania z tzw. social media (http://www.technologie.gazetapl/internet/1,104530,9166120,Wyszukiwanie_i Nasza_Klasa). Najczęściej odwiedzanymi przez respondentów portalami społeczościowymi są: Facebook.com (69,6\% wskazań), Nk.pl (43,2\% wskazań), Goldenline.pl $(3,1 \%)$, Fotka.pl $(2,87 \%)$ i Twitter $(2,61 \%)$. Na portalach społecznościowych ankietowani przeglądają najczęściej profile znajo- mych (58,8\% wskazań), rozmawiają z przyjaciółmi i znajomymi (50,3\% wskazań), także szukają informacji, opinii i wiedzy na temat interesujących ich produktów $(45,8 \%$ wskazań). Uwzględniając z kolei aktywność respondentów na portalach społecznościowych, co drugi badany twierdzi, że robi to codziennie, prawie co czwarty ankietowany - od dwóch do trzech razy w tygodniu, co piąty badany - raz w tygodniu, natomiast niecałe $5 \%$ badanych respondentów przyznaje, że odwiedza portale społecznościowe rzadziej niż raz w tygodniu.

Prawie 44\% ankietowanych korzysta $\mathrm{z}$ Internetu w celu robienia zakupów, z czego ok. 4/5 spotkało się w sieci z opiniami innych osób i firm o ofercie rynkowej. Prawie $1 / 5$ badanych twierdzi, że często traktuje sklepy stacjonarne wyłącznie jako ekspozycje, na których można zapoznać się szczegółowo z konkretnym produktem, a następnie wraca do domu i kupuje go taniej w Internecie. Ponad 2/3 respondentów korzystających z Internetu twierdzi, że przy robieniu zakupów online bierze pod uwage rekomendacje uzyskiwane od przyjaciół i znajomych. W przypadku źródeł internetowych dla ponad $57 \%$ badanych, robiących zakupy online, najbardziej wiarygodne są informacje podawane przez porównywarki cen, dla 49,3\% - informacje i komentarze zamieszczane na forach dyskusyjnych, natomiast dla 42,7\% - zalecenia ekspertów zamieszczane przez nich na blogach i w serwisach społecznościowych. Jedynie co dziesiąty badany twierdzi, że przy podejmowaniu decyzji zakupowych online bierze pod uwagę reklamy zamieszczane w mediach społecznościowych. Respondenci najczęściej nabywają przez Internet: ubrania - 19,4\%, sprzęt elektroniczny - 17,9\%, komputery i akcesoria - 9,3\%, kosmetyki - 8,5\%, książki, w tym książki elektroniczne i audiobooki - 4,9\% i usługi bankowe - 4,8\%. Wśród innych rzeczy ankietowani wymieniają także suplementy diety, bilety na pociagg/autobus/samolot, artykuły budowlane, meble oraz inne elementy wyposażenia mieszkania. Z zakupów online najczęściej korzystają osoby młode do 25. roku życia oraz z grupy wiekowej 26-44 lata, z wykształceniem wyższym lub średnim ogólnokształcącym, o miesięcznych dochodach per capita powyżej 3000,00 zł, mieszkające w Warszawie, Toruniu, Suwałkach i Brzesku. Robiąc zakupy online, ankietowani korzystają głównie z oferty ser- 
wisów ogłoszeniowych (takich jak: Gratka pl, Tablica.pl oraz Gumtree.pl), porównywarek cen (takich jak: Ceneo.pl, Skapiec.pl oraz Nokaut.pl) oraz w mniejszym stopniu z pasaży handlowych i katalogów, wykorzystują do zakupów urządzenia mobilne, a za produkty płacą za pomocą systemów płatności internetowej. Do najczęściej wymienianych zalet robienia zakupów w sieci, respondenci korzystający z zakupów online wskazują: oszczędność pieniędzy $(32,9 \%$ wskazań), lepsze promocje (23,4\% wskazań), oszczędność czasu (17,7\% wskazań) oraz większy wybór asortymentu (14,2\% wskazań).

\section{Wirtualizacja konsumpcji - wyznacznik nowego sposobu komunikowania się i konsumowania}

Wirtualizacja konsumpcji jest alternatywnym trendem konsumenckim, który przybiera na sile $\mathrm{w}$ ciagu ostatnich kilku lat $\mathrm{i}$ jest związany $\mathrm{z}$ rozwojem społeczeństwa sieci oraz zmianami technologicznymi (głównie technologii informacyjnych i telekomunikacyjnych, z których Internet wywiera największy wpływ na zachowania nabywcze konsumentów) ${ }^{10}$. Wirtualizacja oznacza coraz większy udział elektronicznych środków przekazu, takich jak: telewizja, radio czy Internet $\mathrm{w}$ zaspokajaniu potrzeb ludzkich. Ułatwia organizację życia codziennego, natomiast poprzez redukcje ograniczeń związanych z mobilnością konsumentów i informacji oraz umożliwienie bezpośredniego dostępu do produktów i usług, wirtualizacja przyczynia się do kreowania konsumpcji domocentrycznej. Wspomniane media zrewolucjonizowały zachowania konsumpcyjne większości ludzi, zmieniając ich aspiracje, głównie w odniesieniu do dóbr zaspokajających potrzeby wyższego rzędu, a zatem potrzeby w zakresie edukacji, kultury i szeroko pojmowanej rozrywki. Jak twierdzi Cz. Bywalec (2010, s. 223), wirtualizacja przejawia się w olbrzymiej swobodzie użytkowników przy wyborze treści konsumowanych. W dzisiejszych czasach kultura znaku zastępowana jest kulturą obrazu i dźwięku, tj. wizualizacją i fonizacją kultury. Proces wirtualizacji konsumpcji jest niezwykle dynamiczny i napędzany przez intensywny rozwój nowych, innowacyjnych technologii informatycznych. Wraz $\mathrm{z}$ popularyzacją Internetu pojawił się nowy rodzaj komunikowania się ludzi ze światem, nazywany w literaturze przedmiotu samokomunikacją. Blogi, mikroblogi czy portale społecznościowe stały się naturalną częścią codziennego życia olbrzymiej liczby ludzi na całym świecie, same zaś w sobie stały się przedmiotem nie tylko konsumpcji, lecz także prokonsumpcji.

Innowacje technologiczne, w tym rozwój nowych mediów przekazu, nieustannie dynamizują procesy wirtualizacji zachowań konsumentów. W rezultacie można zaobserwować zmiany w poziomie i strukturze konsumpcji, chociażby w zakresie uczestnictwa kulturalnego konsumentów. Można powiedzieć, że wirtualizacja konsumpcji przejawia się w sposobie konsumowania najbardziej popularnych dóbr kulturowych i rozrywkowych, a ponadto koncentruje się na potrzebach jednostek. Cecha charakterystyczna wirtualizacji konsumpcji jest również możliwość przenoszenia potrzeb sfery publicznej do prywatnej. Obejrzenie nowego filmu, przedstawienia teatralnego, koncertu czy zrobienie prostych zakupów może się odbyć bez wychodzenia z domu. Wszystkie te potrzeby konsumenci mogą zaspokoić, korzystając z odpowiednich zasobów Internetu (Latusek i Zalega, 2012, s. 161).

Cechą wirtualizacji zachowań konsumentów jest swoiste kurczenie się czasu i przestrzeni w komunikacji międzyludzkiej za sprawą Internetu i telefonu komórkowego. Nowe technologie zmieniły sposób postrzegania czasu przez ludzi, a także wpłynęły na transformację możliwości i ograniczeń mobilności ludzi i informacji. Zmiany technologiczne i organizacyjne zaistniałe dzięki dynamicznemu rozpowszechnieniu Internetu spowodowały, że w obecnie coraz częściej dokonuje się rozróżnienia między czasem wirtualnym a momentalnym. Główną cecha czasu momentalnego jest zniesienie podziału na dzień i noc, dni robocze i weekendy, dom i miejsce pracy czy wypoczynek i pracę (Urry, 2009, s. 179-180). W rezultacie komputeryzacja społeczeństwa i rozwój Internetu stały się jednym z bardziej widocznych bodźców zmieniających zachowania konsumentów, ponieważ te nie pozostały bez wpływu na: przyjmowane formy komunikacji w życiu i biznesie, definicje odległości w czasie i przestrzeni, powstanie nowych produktów cyfrowych czy zwiększenie dostępności konsumpcji dóbr i usług. Tym samym czynniki te zmieniły niejako aspiracje polskich konsumentów. 
Z przeprowadzonych badań wynika, że prawie połowa ankietowanych korzysta z możliwości oglądania telewizji oraz klipów wideo w Internecie, co trzeci respondent odwiedza portale internetowe (głównie: Facebook.com i Nk.pl), co czwarty korzysta z różnego typu gier internetowych, a niespełna $1 / 5$ ankietowanych regularnie czyta gazety online. Zjawisko wirtualizacji zachowań konsumentów jest najbardziej rozpowszechnione wśród ludzi młodych, głównie mężczyzn, w wieku do 25 . roku życia (87,3\% wskazań) oraz z grupy wiekowej 26-44 lata $(68,7 \%)$, z wykształceniem wyższym lub średnim ogólnokształcącym, o miesięcznych dochodach per capita nieprzekraczających 3000,00 zł, mieszkających w Warszawie $(63,7 \%)$, Wrocławiu $(61,3 \%)$, Gdańsku (59,9\%) i Kostrzynie (57,8\%).

\section{Domocentryzm - powrót do ogniska domowego}

Domocentryzacja (domocentryzm, kokonizacja) konsumpcji jest kolejnym alternatywnym trendem konsumenckim nabierającym na sile w okresie kryzysu gospodarczego. Trend ten polega na przenoszeniu konsumpcji $\mathrm{z}$ instytucji publicznych do domu, który jednocześnie staje się miejscem zaspokajania potrzeb kulturalnych, edukacyjnych, rekreacyjnych w zakresie ochrony zdrowia itp., realizowanych wcześniej poza jego obrębem (np. w kinach, kawiarniach, centrach handlowych). Domocentryzm jest w dużym stopniu konsekwencją: lepszego wyposażenia gospodarstw domowych w sprzęt informacyjno-rozrywkowy wysokiej klasy (telewizory LCD i plazmowe, kino domowe, Video-on-Demand, Payper-View itp.), rozwoju atypowych form zatrudnienia (zwłaszcza telepracy i pracy w niepełnym wymiarze godzin), permanentnie postępującego procesu globalizacji, indywidualizacji stylów życia i ucieczki w prywatność, starzenia sie społeczeństw, upowszechnienia Internetu i telefonii bezprzewodowej, a także poprawy wyposażenia gospodarstw domowych w środki transportu oraz nowoczesne nośniki informacji i przekazu kulturowego (tablety i e-czytniki zmieniają sposób korzystania z dóbr kultury). Domocentryzacja konsumpcji przyczynia się do koncentracji konsumentów na własnym domu i najbliższej rodzinie $\mathrm{i}$, jak to określił A. Hines (2008, s. 19), na zaszyciu się konsumentów w domu i na swoistym celebrowaniu domatorstwa. Można zatem postawić tezę, że powrót do ogniska domowego wynika prawdopodobnie $\mathrm{z}$ odrzucenia koncepcji hiperindywidualizmu, co w naturalny sposób prowadzi do rehabilitacji rodziny i przywrócenia jej wartości nadrzędnej. Wspomniana ucieczka w prywatność jest rozpowszechniona zwłaszcza wśród tych osób, które mają możliwość wykonywania pracy zawodowej $\mathrm{w}$ domu (np. telepraca). Należy również wspomnieć, że technologie wykorzystywane w domocentryzmie, ze wzgledu na ciągły kontakt z całym światem, przyczyniły się do rozwoju trendu „non-stop”. Polega on na eliminowaniu z życia przerw i przestojów traktowanych jako nieproduktywne, wypełnianiu czasu „w drodze” poprzez Internet bezprzewodowy, jedzenie w drodze (produkty on-the-go) oraz logistycznej optymalizacj funkcjonowania gospodarstw domowych (np. zamawianiu usług za pomocą SMS, wykorzystaniu technologii GPS).

W okresie kryzysu gospodarczego domocentryzacja okazuje się bardzo korzystna dla wielu konsumentów, ponieważ ułatwia organizację życia codziennego, sprzyja zaspokajaniu odczuwanych potrzeb, a przy okazji generuje oszczędności w gospodarstwach domowych.

Z przeprowadzonych badań wynika, że prawie połowa respondentów informowała o konieczności asygnowania coraz mniejszych kwot na cele edukacyjne, związane z kształceniem dzieci. Najcześciej ankietowane gospodarstwa domowe były zmuszone, ze wzgledów finansowych, do rezygnacji z dodatkowych zajęć i korepetycji dla dziecka. Co czwarty badany posiadający dziecko/dzieci z przyczyn finansowych zmuszony został do ograniczenia dodatkowych płatnych zajęć dla dziecka/dzieci, natomiast prawie co piąty ankietowany ze względów finansowych musiał zrezygnować z korepetycji dla dziecka/dzieci. Jedynie $18,8 \%$ badanych było zdania, że kryzys gospodarczy w żaden sposób nie wpłynął na opłaty związane $\mathrm{z}$ dodatkowymi płatnymi zajecciami, na które uczęszcza/ją dziecko/dzieci. Ponad $37 \%$ respondentów przyznało, że w ogóle nie stwarza swoim dzieciom takiej możliwości. Czynnikiem decydującym o rezygnacji z zajęć dodatkowych i korepetycji dla dziecka/dzieci jest niewatpliwie zamożność gospodarstw domowych. Najrzadziej ograniczenia związane z kształceniem dzieci wykazywały gospodarstwa domowe dyspo- 
nujące miesięcznym dochodem per capia powyżej 3000,00 zł, zamieszkujące głównie Warszawę, Wrocław i Gdańsk. Najczęściej rezygnowały $\mathrm{z}$ tych usług gospodarstwa dysponujące miesięcznym dochodem na 1 osobę nieprzekraczającym 1000,00 zł, czyli te, których sytuacja dochodowa jest najtrudniejsza, mieszczące się głównie w Łowiczu, Brzesku i Kostrzynie.

W ankietowanych gospodarstwach domowych zaobserwowano ograniczenie wydatków na sport, turystykę i wypoczynek. $\mathrm{Z}$ przeprowadzonych badań wynika, że największe ograniczenia $\mathrm{w}$ tym zakresie poczyniły gospodarstwa domowe z Brzeska $(23,2 \%)$, Torunia $(21,8 \%)$, Warszawy $(18,7 \%)$ i Lowicza $(17,9 \%)$. Natomiast ograniczenie wydatków na kulturę sygnalizowało prawie 2/5 ankietowanych, najczęściej mieszkających w Toruniu $(41,8 \%)$ Brzesku (40,3\%) i Kostrzynie (39,7\%). Prawie połowa respondentów twierdziła, że zrezygnowała bądź poważnie ograniczyła wyjścia do kina i teatru. Co piąty ankietowany przyznał się do samodzielnego organizowania wypoczynku dla rodziny, co trzeci zaś - wybierał tańsze oferty agencji turystycznych.

$\mathrm{Z}$ kolei wydatki na usługi gastronomiczne uległy stosunkowo niewielkiemu zmniejszeniu. Należy zaznaczyć, że mimo kryzysu gospodarczego stołowanie się poza domem cieszy się wśród polskich konsumentów dużą popularnością. Jedynie 14\% ankietowanych stwierdziło, że całkowicie rezygnuje ze spożywania posiłków poza domem, $23 \%$ było zaś zdania, że ogranicza wyjścia do lokali gastronomicznych w ciągu miesiaca. Byli to przeważnie respondenci z mniejszych miejscowości, takich jak Suwałki $(23,7 \%)$, Lowicz $(20,7 \%)$ i Brzesko $(19,7 \%)$. Z przeprowadzonych badań wynika ponadto, że kryzys gospodarczy spowodował wśród ankietowanych konsumentów większe zainteresowanie lokalami fast food, pubami, pizzeriami, a także barami mlecznymi. Uwzględniając cechy socjodemograficzne ankietowanych, fast foody, puby i pizzerie odwiedzali najczęściej ludzie młodzi do 25 . roku życia oraz ankietowani z grupy wiekowej 26-44 lata, podatni na różne przejawy globalizacji, najczęściej mężczyźni, legitymujący się wykształceniem średnim ogólnokształcacym i wyższym, mieszkający głównie w Warszawie $(31,8 \%)$, Wrocławiu (30,2\%), Gdańsku $(29,7 \%)$ i Toruniu (28,6\%). Z oferty barów mlecz- nych korzystały najczęściej osoby w wieku 65 lat i więcej, o podstawowym i zasadniczym zawodowym poziomie wykształcenia, mieszkający w Warszawie (19,3\%), Toruniu $(17,7 \%)$ i Suwałkach $(16,4 \%)$. Można zatem pokusić się o stwierdzenie, że konsumenci o bardziej utrwalonych przyzwyczajeniach są skłonni wybrać tańszą ofertę, niż całkowicie zrezygnować ze stołowania się poza domem.

Prawie co czwarty ankietowany był zdania, że na skutek pogorszenia się sytuacji materialnej rodziny spowodowanej kryzysem wytwarza produkty i usługi we własnym zakresie. Chodzi tu przede wszystkim o uprawianie warzyw i owoców $(21,7 \%)$, majsterkowanie i samodzielne wykonywanie remontów mieszkania $(20,3 \%)$ oraz szeregu drobnych prac związanych $\mathrm{z}$ naprawą sprzętu domowego $(18,6 \%)$. Najcześciej korzystanie $\mathrm{z}$ wymienionych form samozaopatrzenia, czyli tzw. konsumpcji własnej (wpisujących się po części w domocentryzm i freeganizm) wskazywali respondenci z Kostrzyna (26,1\%), Łowicza (24,7\%), Suwałk $(23,4 \%)$ i Brzeska $(21,6 \%)$.

\section{Podsumowanie}

Na podstawie przeprowadzonego badania można konstatować, że:

1. Kryzys gospodarczy, zmuszając miejskie gospodarstwa domowe w Polsce do ograniczenia wydatków, niewątpliwie prowadzi do określonych przekształceń w zachowaniach nabywczych konsumentów oraz w realizowanych wzorach spożycia.

2. Większość $z$ ankietowanych gospodarstw domowych, których sytuacja finansowa uległa pogorszeniu w porównaniu z okresem sprzed kryzysu, podjęła próbę racjonalizowania zakupów. Owa racjonalizacja przejawiała się często w poszukiwaniu tańszych produktów kosztem ich droższych odpowiedników, rezygnacji z pewnych zakupów i usług bądź korzystaniu z różnego rodzaju promocji organizowanych przez sieci dyskontowe oraz superi hipermarkety.

3. Trendami nabierającymi na sile w okresie kryzysu gospodarczego wśród miejskich gospodarstw domowych w Polsce sa: konsumpcja kolaboratywna, świadoma konsumpcja, sprytne zakupy, freeganizm, social media, wirtualizacja konsumpcji oraz domocentryzm. 
4. Siła zmian w zachowaniach nabywczych miejskich konsumentów wywołana kryzysem gospodarczym jest uzależniona w największym stopniu od wysokości i stabilności dochodów ankietowanych gospodarstw domowych.

5. W warunkach kryzysu słabnie trend do serwicyzacji, który przejawia się w ograniczeniu wydatków na usługi. Wzrasta natomiast znaczenie domocentryzacji konsumpcji, która sprzyja zaspakajaniu odczuwanych potrzeb oraz ułatwia organizację życia codziennego w wielu gospodarstwach domowych.

6. Kupowanie najtańszych produktów oraz wybieranie marek własnych sklepów jest zachowaniem charakterystycznym dla ankietowanych legitymujacych sie wykształceniem podstawowym i zasadniczym zawodowym, natomiast wśród respondentów posiadających wykształcenie wyższe, ważną rolę odgrywa konsumpcja oparta na świadomej i przemyślanej konsumpcji.

7. Konsumenci w dobie kryzysu przywiązują większą wagę do promocji cenowych oraz preferują komunikację nastawioną na racjonalne argumenty, a nie na emocje.

8. W warunkach kryzysu gospodarczego ankietowane gospodarstwa domowe wykazują większą skłonność do korzystania $z$ różnych form samozaopatrzenia, dotyczącego wytwarzania produktów i usług we własnym zakresie.

9. Nowe trendy w zachowaniach nabywczych gospodarstw domowych w okresie kryzysu są bardziej dostrzegalne wśród mieszkańców dużych aniżeli małych miast.

\section{Przypisy}

1 Jak dowodzą badania przeprowadzone przez D. Ariely'ego (2008, s. 84-119), wzrost wydatków konsumpcyjnych gospodarstw domowych jest w dużym stopniu konsekwencją promocji sklepowych, które wywołują tzw. efekt pieniędzy kasyna. Z badań tych wynika dobitnie, że konsumenci w swoich decyzjach zakupowych kierują się głównie celami krótkookresowymi. Wydając posiadane środki pieniężne na bieżącą konsumpcje, praktycznie traca z oczu perspektywę długofalową, związaną ze swoim zdrowiem, sylwetką sprawnością itd. Wspomniane badania Ariely'ego, a także seria badań przeprowadzonych przez D. Khanemana i A. Tversky'ego (1979, s. 263-291) oraz A.R. Damasio (1994 s. 87-137), w sposób stanowczy doprowadziły do zakwestionowania paradygmatu ekonomicznego, zakładajacego racjonalność zachowań konsumentów w procesie podejmowania decyzji konsumpcyjnych na rynku. Zgodnie z nowym paradygmatem, na którym opiera się ekonomia behawioralna, zachowania nabywcze konsumentów mają charakter głównie emocjonalny. Wynika z niego, że gospodarstwa domowe podejmują decyzje konsumpcyjne pod wpływem oddziaływania całego wachlarza różnorodnych bodźców, a nie rachunku ekonomicznego. Okazuje się, że strona emocjonalna zachowań konsumentów jest znacznie silniejsza niż sfera racjonalna.

2 Wyraz oniomania (z gr. wvíos - sprzedawany) został wprowadzony przez niemieckiego lekarza Emila Kraepelina na określenie chorobliwego uzależnienia od chęci nabywania dóbr i usług, spędzania wolnego czasu na zakupach. Jego potocznym synonimem jest shopoholizm (z ang. to shop - nabywać, chodzić po zakupy).

3 Na terenie poszczególnych miast badania ankietowe zostały przeprowadzone na osiedlach:

Warszawa: Boernerowo, Grochów-Południe, Imielin, Jelonki, Kabaty, Nadwiśle, Nowodwory, Pelcowizna, Piaski, Pyry, Radość, Sadyba, Salomea, Szczęśliwice, Tarchomin, Utrata, Wrzeciono, Zacisze i Zawody.

Wrocław: Gaj, Grabiszyn, Klecina, Kowale, Leśnica, Nowy Dwór, Oporów, Pilczyce, Ratyń, Tarnogaj i Zakrzów.

Gdańsk: Aniołki, Brzeźno, Nowy Port, Osowa, Przymorze Wielkie, Siedlce, Stogi, Strzyża, Zaspa-Młyniec i Żabianka.

Toruń: Bielawy, Grębocin nad Strugą, Na Skarpie, Rubinkowo i Wrzosy.

Suwałki: Daszyńskiego, Hańcza, Kamena, Północ II i Zielony Zakątek.

Łowicz: Bratkowice, Czajki, Dabrówka, Kostka i Lotników.

Brzesko: Grady, Kołłąaja, Ogrodowa, Solskiego i Władysława Jagiełly.

Kostrzyn: Gułtowy, Piasta, Półwiejska, Rycerza Kostro i Wiktorowo.

4 Świadoma konsumpcja związana jest z zasadą 3R, której nazwa jest skrótem pochodzącym od trzech angielskich czasowników: reduce, reuse i recycle. Pierwszy czasownik oznacza w języku polskim tyle co ogranicz i zachęca do zmniejszenia konsumpcji i rezygnacji z kupowania nowych i często niepotrzebnych rzeczy. Z kolei czasownik reuse oznacza w języku polskim $u \dot{z y j}$ ponownie i skłania, o ile to możliwe, do wielokrotnego używania produktów bądź produktów wielokrotnego użytku, co w efekcie przyczyni się do ograniczenia produkcji śmieci. Natomiast czasownik recycle oznacza recykluj, czyli przetwórz i zachęca do sortowania odpadów, co umożliwia ich ponowne wykorzystanie i w ten sposób chroni środowisko przed nadmierna eksploatacją i zaśmieceniem. Mając to wszystko 
na uwadze można powiedzieć, że świadoma (etyczna) konsumpcja jest często określana jako pewnego rodzaju pomysł na naprawę współczesnego świata za pomocą „własnego portfela”.

5 Specyficznym rodzajem świadomej konsump cji jest ekobuddyzm, który polega na zakupie żywności ekologicznej oraz produktów sprawiedliwego handlu będącego wyrazem poparcia dla przestrzegania praw człowieka. Innym słowy, z buddyzmem ekologicznym mamy do czynienia wówczas, gdy: ograniczamy konsumpcję i nabywamy wybrane kategorie produktów (np. energooszczędne żarówki), robimy zakupy blisko swego miejsca zamieszkania, oszczędzamy i inwestujemy swoje pieniądze w sposób odpowiedzialny, unikamy kupowania danych kategorii produktów, do których mamy krytyczny stosunek (np. jajek z chowu klatkowego, samochodów spalających duże ilości paliwa) oraz nabywamy produkty używane oraz z recyclingu.

6 Slow food przeciwstawia się szybkiemu, wygodnemu, ale jednocześnie niezdrowemu i nieracjonalnemu życiu. Innymi słowy slow food, propagując powolny styl życia, którego symbolem jest ślimak, propaguje prawo do smaku, który zgubiliśmy w cywilizacji konsumpcji, odnosi się do decyzji konsumentów, które są cechują się racjonalnościa

7 Konsumpcja kolaboratywna opiera się na ide współdzielenia i tzw. produkt sernice approach, czyli skupieniu się na funkcji produktu bez konieczności posiadania go na własność. Innymi słowy, nie potrzebujemy płyty DVD, tylko filmu, który możemy z niej obejrzeć; po przeczytaniu książki możemy wymienić ja na inna. Rozwiązania z nurtu konsumpcji współpracującej sięgają od zwykłej sąsiedzkiej wymiany przysług, przez różnego typu biblioteki, po coraz bardziej rozpowszechnione w Europie rowery miejskie (system, który pozwala mieszkańcom krótkoterminowo korzystać z rowerów ustawionych na specjalnych stanowiskach w wybranych punktach miasta) czy systemy współdzielenia samochodów (np. ZipCar). Według R. Botsman coraz więcej współczesnych konsumentów zamiast skupiać się na posiadaniu, większą wagę zaczyna przywiązywać do funkcji, przeżyć lub doświadczeń związanych z konkretnym produktem, a nastepnie przekazuje go dalej. Konsumpcja kolaboratywna nie tylko pozwala ograniczyć konsumpcję indywidualną i niepotrzebne zakupy, lecz także wzmacnia integrację i więzi społeczne. Szerzej na temat konsumpcji kolaboratywnej w: Gansky (2010); Shirky (2010); Botsman i Rogers (2012).

8 Zwolennicy wymiany swoich ubrań, ksiązek, biżuterii lub niechcianych prezentów na inne, dokonywane bezgotówkowo, czyli z ręki do ręki, to moda na oszczędzanie i ekologiczność w niebanalnym stylu zwana popularnie swappingiem. Tego typu moda odbywa się na tzw. swap parties organizowanych regularnie (za pośrednictwem portali internetowych) w niektórych dużych miastach Polski (m.in. w Warszawie, Łodzi, Krakowie, Wrocławiu, Poznaniu i Szczecinie). Entuzjaści swappingu ustalili nawet 10 października Ogólnopolskim Dniem Bezgotówkowej Wymiany Ciuchów.

9 LOHAS to termin użyty po raz pierwszy przez amerykańskich socjologów na przełomie XIX i XX wieku. Konsumenci zaliczani do tej grupy, wybierając produkty zawsze kierują się wartościami społecznymi i środowiskowymi. Oprócz redukowania własnego negatywnego wpływu na środowisko, niezwykle istotny jest dla Lohasów rozwój osobisty i pełne wykorzystanie własnego potencjału, oraz dążenie do osiągnięcia równowagi miedzy tym co otrzymują i oddają środowisku, a także między ciałem i duchem. Lohasami sa głównie ludzie młodzi, dobrze wykształceni i dużo zarabiający oraz mieszkający w dużych miastach bądź metropoliach.

10 Wirtualizacja oraz fonizacja konsumpcji spowodowały rozwój nowego trendu nazywanego multitaskingiem, który jest umiejętnością wykonywania wielu czynności i zadań jednocześnie. Trend ten można zaobserwować praktycznie w życiu codziennym konsumentów, przy słuchaniu muzyki i równoczesnym czytaniu gazety czy przeglądaniu stron internetowych i równoczesnym korzystaniu z komunikatorów. Większość nowych urządzeń przenośnych, np. tabletów, daje możliwość jednoczesnego korzystania przez użytkowników z wielu aplikacji. Prawie każde nowe urządzenie typu telefon komórkowy czy e-czytnik, oprócz swoich podstawowych funkcji, umożliwia równoczesne odtwarzanie plików tekstowych, graficznych i dźwiękowych.

\section{Bibliografia}

Ariely, D. (2008). Predictably Irrational: The Hidden Forces That Shape Our Decision. New York: Harper Collins.

Bohlen, B., Carlotti, S. i Mihas L. (2010). How the recession has changed US consumer behavior, McKinsey Quarterly, 1.

Botsman, R. i Rogers R. (2012). What's Mine Is Yours: The Rise of Collaborative Consumption. New York: Harper Collins.

Bywalec, Cz. (2010). Konsumpcja a rozwój gospodarczy $i$ społeczny. Warszawa: Wydawnictwo C.H. Beck. Damasio, A.R. (1994). Descartes Terror: Emotion, Reason and the Human Brain. New York: Putnam.

Desvaux, G., Regaout, B., Labaye, B., Yu, F. i Mednonca, L. (2009). Beating the Recession: Buying into New European Consumer Strategies. McKinsey Global Institute.

Flatters, P. i Willmott, M. (2009). Understanding the post-recession consumers', Harvard Business Review, 7(7/8). 
Gansky, L. (2010). The Mesh: Why the Future of Business Is Sharing. New York: Penguin Books.

Global Consumer Confidence, Concerns and Spending a Global Nielsen Consumer Report (2009). Nielsen.

Graham, J. (2010). Critical Thinking in Consumer Behavior: Cases and Experiential Exercises. New Jersey: Prentice Hall.

Hermann, S. (2009). The crisis and consumer behavior: eight quick solution, Journal of Consumer Behavior, 8(2).

Hines, A. (2009). Consumer trends in three different worlds, The Futurist, July-August.

Inklaar, R. i Yang J. (2012). The impact of financial crisis and tolerance for uncertainty, Journal of Development Economics, 92(2).

Khaneman, D. i Tversky, A. (1979). Prospect Theory: An Analysis of Decision under Risk, Econometrica, 47.

Kaplan, A.M. i Haenlein, M. (2010). Users of the world, unite! The challenges and opportunities of Social Media, Business Horizons, 53(1), Kelley School of Business, Indiana University.

Kaplan, A.M. i Haenlein, M. (2012). Social Media: Back to the roots and back to the future, Journal of Systems and Information Technology, 14(2).

Kotler, Ph. i Caslione, J.A. (2009). Chaos. Zarzadzanie i marketing $w$ erze turbulencji. Warszawa: MT Biznes.

Latusek, M. i Zalega, T. (2012). Trendy w konsumpcji na rynku książki elektronicznej, Studia $i$ Materiaty, 14-15(1-2), Warszawa: Wydawnictwo Naukowe WZ UW.

Mazurek-Łopacińska, K. (2010). Skutki światowego kryzysu gospodarczego dla indywidualnych konsumentów. W: Tendencje zachowań konsumenckich na regionalnym rynku, Problemy Zarzadzania, Finansów i Marketingu, 16, Zeszyty Naukowe nr 609 US, Szczecin.

NM Incite (2012). A Nielsen/McKinsey Company, State of the Media: Social Media Report Q3 Pobrano z: www.nmincite.com (15.04. 2013)

Shaw, F. (2009). Uncertainty and the New Consumer, Foresight, 4.
Shirky, C. (2010). Cognitive Surplus: How Technology Makes Consumers in to Collaborators. New York: Penguin Books.

Sojkin, B., Małecka, M., Olejniczak, T. i Bakalarska, M. (2009). Konsument wobec innowacji produk towych na rynku żywności. Poznań: Wydawnictwo Uniwersytetu Ekonomicznego w Poznaniu.

Urry, J. (2009). Socjologia mobilności. Warszawa: Wydawnictwo Naukowe PWN.

Vejlgaard, H. (2008). Anatomy of trend. New York: McGraw-Hill.

Zalega, T. (2008). Konsumpcja $w$ gospodarstwach domowych o niepewnych dochodach. Warszawa: Wydawnictwo Uniwersytetu Warszawskiego.

Zalega, T. (2012a). Przyczyny i konsekwencje współczesnego kryzysu finansowo-ekonomicznego. W: A.P. Wiatrak (red.), Aktualne problemy zarzadzania - teoria i praktyka. Monografia naukowa z okazji 40-lecia Wydziału Zarzadzania Uniwersytetu Warszawskiego. Warszawa: Wydawnictwo Uniwersytetu Warszawskiego.

Zalega, T. (2012b). Konsumpcja w wielkomiejskich gospodarstwach domowych w Polsce w okresie kryzysu finansowo-ekonomicznego. Warszawa: Wydawnictwo Naukowe WZ UW.

http://www.socialpress.pl/2011/12/ponad-miliardinternautow-korzysta-z-social-media?\# (13.03.2012).

www.technologie.gazetapl/internet/1,104530,9166120, Wyszukiwanie_i_Nasza_Klasa (15.03.2012).

www.biznesodpowiedzialnie.blog.pl/tag/kontenerowcy (03.08.2012).

www.elejdis.pl/692,Freeganizm (12.10.2012).

www.fed.home.pl/teg/images/m1_swiadoma_konsumpcja_fin.pdf (10.08.2012).

www.interaktywnie.com/biznes/newsy/biznes/takwyglda-konsumpcja-internetu-wsrod.mezczyzn-ikobiet-245942 (08.04.2013).

www.m.onet.pl/biznes,cbjb (25.09.2012).

www.rp.pl/artykul/590077_Kleska-malychsklepowna-rynku-coraz-gorzej.html (15.12.2012).

www.trendwatching.com,http://pl.nielsen.com/ trends/documents/GlobalConsumerConfidenceConcernsandSpendingMay2009.pdfNielse (10.06.2010). 